\title{
Herbivore biocontrol and manual removal successfully reduce invasive macroalgae on coral reefs
}

\author{
Brian J Neilson ${ }^{\text {Corresp., }}$, $^{\text {, Christopher B Wall }}{ }^{2}$, Frank T Mancini ${ }^{2}$, Catherine A Gewecke $^{1}$ \\ ${ }^{1}$ State of Hawai'i Division of Aquatic Resources, Honolulu, Hawai'i, United States \\ ${ }^{2}$ Hawai'i Institute of Marine Biology, University of Hawai'i at Mānoa, Kāne'ohe, Hawai'i, United States \\ Corresponding Author: Brian J Neilson \\ Email address: brian.j.neilson@hawaii.gov
}

Invasive macroalgae pose a serious threat to coral reef biodiversity by monopolizing reef habitats, competing with native species, and directly overgrowing, and smothering reef corals. Several invasive macroalgae (Eucheumaclade E, Kappaphycus clade A and B, Gracilaria salicornia, and Acanthophora spicifera) are established within Kāne'ohe Bay (O'ahu, Hawai'i, USA), and reducing invasive macroalgae cover is a coral reef conservation and management priority. Invasive macroalgae control techniques, however, are limited and few successful large-scale applications exist. Therefore, a two-tiered invasive macroalgae control approach was designed, where first, divers manually remove invasive macroalgae (Eucheumaand Kappaphycus) aided by an underwater vacuum system ("The Super Sucker"). Second, hatchery-raised juvenile sea urchins (Tripneustes gratilla), were outplanted to graze and control invasive macroalgae regrowth. To test the effectiveness of this approach in a natural reef ecosystem, four discrete patch reefs with high invasive macroalgae cover (15 - $26 \%$ ) were selected, and macroalgae removal plus urchin biocontrol (treatment reefs, $n=2$ ), or no treatment (control reefs, $n=2$ ), was applied at the patch reef-scale. In applying the invasive macroalgae treatment, the control effort manually removed $\sim 19,000 \mathrm{~kg}$ of invasive macroalgae and $\sim 99,000$ juvenile sea urchins were outplanted across to two patch reefs, totaling $\sim 24,000 \mathrm{~m}^{2}$ of reef area. Changes in benthic cover were monitored over two years (five sampling periods) before-and-after the treatment was applied. Over the study period, removal and biocontrol reduced invasive macroalgae cover by $85 \%$ at treatment reefs. Our results show manual removal in combination with hatchery raised urchin biocontrol to be an effective management approach in controlling invasive macroalgae at reef-wide spatial scales and temporal scales of months to years. 
1 Herbivore biocontrol and manual removal successfully reduce invasive macroalgae on 2 coral reefs

3 B.J. Neilson ${ }^{*}$, C.B. Wall ${ }^{2}$, F.T. Mancini' ${ }^{2}$, C.A. Gewecke ${ }^{1}$

4 Short title: Invasive macroalgae control

5 *Corresponding author: tel (808) 227-7677; email: brian.j.neilson@hawaii.gov

$6 \quad{ }^{1}$ State of Hawai 'i Division of Aquatic Resources, Honolulu, HI 96813

7 2University of Hawai'i at Mānoa, Hawai'i Institute of Marine Biology, Kāne‘ohe, HI 96744 


\section{ABSTRACT}

9 Invasive macroalgae pose a serious threat to coral reef biodiversity by monopolizing reef

10 habitats, competing with native species, and directly overgrowing, and smothering reef corals.

11 Several invasive macroalgae (Eucheuma clade E, Kappaphycus clade A and B, Gracilaria

12 salicornia, and Acanthophora spicifera) are established within Kāne'ohe Bay (O`ahu, Hawai'i,

13 USA), and reducing invasive macroalgae cover is a coral reef conservation and management

14 priority. Invasive macroalgae control techniques, however, are limited and few successful large-

15 scale applications exist. Therefore, a two-tiered invasive macroalgae control approach was

16 designed, where first, divers manually remove invasive macroalgae (Eucheuma and

17 Kappaphycus) aided by an underwater vacuum system (“The Super Sucker"). Second, hatchery-

18 raised juvenile sea urchins (Tripneustes gratilla), were outplanted to graze and control invasive

19 macroalgae regrowth. To test the effectiveness of this approach in a natural reef ecosystem, four

20 discrete patch reefs with high invasive macroalgae cover $(15-26 \%)$ were selected, and

21 macroalgae removal plus urchin biocontrol (treatment reefs, $n=2$ ), or no treatment (control

22 reefs, $n=2$ ), was applied at the patch reef-scale. In applying the invasive macroalgae treatment,

23 the control effort manually removed $\sim 19,000 \mathrm{~kg}$ of invasive macroalgae and $\sim 99,000$ juvenile

24 sea urchins were outplanted across to two patch reefs, totaling $\sim 24,000 \mathrm{~m}^{2}$ of reef area. Changes

25 in benthic cover were monitored over two years (five sampling periods) before-and-after the

26 treatment was applied. Over the study period, removal and biocontrol reduced invasive

27 macroalgae cover by $85 \%$ at treatment reefs. Our results show manual removal in combination

28 with hatchery raised urchin biocontrol to be an effective management approach in controlling

29 invasive macroalgae at reef-wide spatial scales and temporal scales of months to years. 


\section{INTRODUCTION}

32 Non-native macroalgae have been introduced worldwide (Schaffelke, Smith \& Hewitt, 2006) as

33 a result of spread through vectors including biofouling, ballast water, the aquarium trade, and

34 seaweed mariculture (Ruiz et al., 2000; Zemke-White \& Smith 2006; Williams \& Smith 2007).

35 Commercial macroalgae production has increased considerably in the last 50 years, becoming a

36 multi-billion dollar industry in over 150 countries (FAO, 2015; Loureiro, Gachon \& Rebours

37 2015). Macroalgae mariculture occurs throughout tropical regions often cultivating non-native

38 or domesticated species of the genera Caulerpa spp., Eucheuma spp., Gracilaria spp., and

39 Kappaphycus spp. (Zemke-White \& Smith 2006; FAO, 2015; Radulovich et al., 2015). The

40 macroalgae industry can provide economic opportunities for coastal communities and can offer a

41 viable alternative to fisheries-based economies (Pickering \& Forbes, 2002; Mate, Namudu \&

42 Lasi, 2003). However, macroalgae production can have inadvertent consequences for tropical

43 reef biodiversity (Smith et al., 2001; Stimson et al., 2001; Ballesteros, 2006; Kružić, et al., 2008;

44 Longnecker, Bolicjm \& Kawamoto, 2011; Martinez et al., 2012; Sellers, Saltonstall \& Davidson

45 2015), contributing to a suite of anthropogenic pressures that are driving the global decline of

46 live coral (Bruno \& Selig 2007; Gardner et al., 2003; Pandolfi et al., 2003; De'ath et al., 2012).

47 Following the 2014-2015 global coral bleaching events (van Hooidonk, Maynard \& Planes,

48 2014; Eakin et al., 2017; Hughes et al., 2017) there is a need for immediate action to protect and

49 restore coral reefs worldwide, including the management of invasive macroalgae on coral reefs.

51 Invasive macroalgae have the potential to negatively impact coral reefs by overgrowing reef

52 building corals, outcompeting native species, and altering benthic habitat and the aquatic

53 environment (i.e., chemistry, irradiance, sediment loading) (Russell, 1983; Woo, 2000; Conklin 
54 \& Smith, 2005; Chandrasekaran et al., 2008; Rasher \& Hay, 2010; Martinez, Smith \&

55 Richmond, 2012; Davidson et al., 2015; Sellers, Saltonstall \& Davidson 2015; Murphy \&

56 Richmond, 2016). Macroalgae contribute to ecosystem phase shifts from coral-dominated to

57 macroalgae-dominated reefs (Done, 1992; Mumby et al. 2015, Dell et al. 2016, van de Leemput

58 et al. 2016). Such shifts to macroalgae dominance are generally associated with eutrophication,

59 limited herbivory, or a combination of the two (Smith et al., 1981; Lapointe, 1997; Larned, 1998;

60 Smith, Smith \& Hunter, 2001; Stimson, Larned \& Conklin, 2001; Thacker, Ginsburg \& Paul,

61 2001; Vermeij et al., 2009). Phase shifts involving invasive macroalgae may pose additional

62 competitive advantage over the native ecosystem. For instance, mariculture strains may have

63 been selected for high growth and reproductive rates, vegetative propagation (Naylor et al. 2001;

64 Ask \& Azanza 2002; Zhang et al. 2007), may be more tolerant of disturbed areas (Byers, 2002;

65 Ruiz et al., 1999) and have limited preference by herbivores (Nyberg \& Wallentinus 2005;

66 Boudouresque et al., 1996; Schaffelke, Evers, \& Walhorn 1995). Considering the wide range of

67 ecosystem services coral reefs provide (i.e., food security, tourism, shoreline protection, and

68 cultural value) (Moberg \& Folke, 1999), control and reduction of invasive macroalgae are a

69 management priority for coral reef conservation.

71 Diverse techniques have been applied to eradicate or control marine macroalgae and include

72 manual, chemical, and biological treatments (reviewed by Anderson, 2007). The type of

73 technique applied depends on the management objective (i.e., eradication or control) and is often

74 site and species specific (Anderson, 2007). Examples include chemical treatments (i.e., bleach,

75 salt), thermal treatments (i.e., cold shock, heating), osmotic shock (i.e., freshwater and salinity

76 treatments) (Cheshire et al., 2002; Williams \& Smith, 2004; Wotton et al., 2004; Glaspy, Cresse 
$77 \&$ Gibson, 2005; Anderson, 2007), mechanical or manual removal by hand and/or aided by

78 vacuum or dredge pumps (Curiel et al., 2001; Miller et al., 2004; Hewitt et al., 2005; Conklin,

79 2007; Marks, Reed \& Obaza, 2017), light attenuation, containment barriers, and water-removal

80 with in situ desiccation (Anderson, 2007).

81

82 Biocontrol of invasive macroalgae is a newly emerging and promising macroalgae control

83 technique. For instance, experimental use of sea urchins and mollusks in controlling invasive

84 macroalgae species such as Caulerpa taxifolia, Caulerpa racemosa, and Codium fragile has been

85 evaluated in the Mediterranean and Atlantic (Boudouresque, Lemée \& Meinesz, 1996; Thibaut \&

86 Meinesz, 2000; Scheibling \& Hatcher, 2007; Cebrian et al., 2009). These studies revealed

87 successful biocontrol applications have the highest impact in areas of low infestation (Scheibling

88 \& Hatcher, 2007; Cebrian et al., 2009) and suggest invertebrate biocontrols are most effective for

89 emerging populations of invasive macroalgae. In some cases, the effectiveness of these

90 treatments has been limited by macroalgae toxicity to biocontrol agents (Boudouresque et al.,

91 1996), as well as the speed and the ability to produce and deploy adequate densities of biocontrol

92 grazers to affected areas (Thibaut, 2000). Macroalgae abatement from herbivore biocontrol has

93 recently shown promise on Hawai'i's reefs. The short-spined sea urchin, Tripneustes gratilla

94 (Linnaeus) is a generalist herbivore native to Hawai' $i$ and will feed on at least five species of

95 invasive macroalgae (Stimson, Cunha \& Philippoff, 2007; Westbrook et al., 2015). T. gratilla

96 has the potential for application as an invasive macroalgae biocontrol agent and has been shown

97 to reduce macroalgae biomass within cage-enclosures in situ (Conklin \& Smith, 2005; Stimson,

98 Cunha \& Philippoff, 2007; Chon, 2014; Westbrook et al., 2015). Moreover, T. gratilla has low

99 mobility, can be easily handled, and maricultured from wild urchin stock and outplanted as 
100 juveniles ( $\sim 2.5 \mathrm{~cm}$ test diameter). Finally, T. gratilla achieves its maximum growth rate within

101 the first two-years of life, and test size can reach $5.6-8.3 \mathrm{~cm}$ while grazing on invasive

102 macroalgae species (Pan, 2012).

103

104 Invasive macroalgae are prominent in the Hawaiian archipelago. As a result, a number of

105 aforementioned macroalgae control techniques have been tested in Hawai'i (Smith et al., 2004;

106 Conklin \& Smith, 2005). Nineteen documented species of macroalgae have been introduced into

107 Hawai'i since the 1950's, concentrated primarily on the island of O'ahu where the main shipping

108 and military ports are located (Russell, 1992; Smith, Hunter \& Smith, 2002; DLNR, 2003).

109 Several Rhodophyta macroalgae species have been particularly successful at invading Hawaiian

110 reef communities, including Eucheuma clade E (N.L. Burman) F.S. Collins \& Hervey, and

111 Kappaphycus clade A and clade B (Doty) Doty ex P.C. Silva (Conklin, Kurihara \& Shirwood,

112 2009), Acanthophora spicifera (Vahl) Børgesen, and Gracilaria salicornia (C. Agardh) E.Y.

113 Dawson. The introduction of these macroalgae to Hawai' $i$ in the mid-20 $0^{\text {th }}$ century occurred

114 through a variety of pathways including ship biofouling, ballast water discharge, and mariculture

115 experimentation and production (Doty, 1961; Russell, 1983; Russell, 1992; Smith, Hunter \&

116 Smith, 2002).

117

118 Three Eucheumoid species of the genus Kappaphycus and Eucheuma from the Philippines, were

119 intentionally planted on reefs around Moku o Lo“e Island (Coconut Island) at the Hawai'i

120 Institute of Marine Biology (HIMB) (Kāne‘ohe Bay, Hawai‘i) for experimentation in the 1970’s

121 (Doty, 1977; Russell, 1983). Molecular techniques (Zuccarello, Smith \& West, 2006; Conklin,

122 Kurihara \& Shirwood, 2009) have identified these species as Kappaphycus clade A, 
123 Kappaphycus clade B, and Eucheuma clade E (hereafter Eucheuma). Prior to this analysis,

124 nomenclature for these species has been inconsistent; therefore, we will refer to this group

125 collectively as $E / K$ hereafter unless referring specifically to species. $E / K$ was left unchecked in

126 Kāne'ohe Bay for over two decades, and by 1996, E/K had spread $>5 \mathrm{~km}$ from Moku o Lo'e

127 Island and were found throughout Kāne'ohe Bay (Rodgers \& Cox, 1999) and continued to

128 spread to previously unaffected northern reefs adjacent to Kāne'ohe by 1999 (Conklin \& Smith,

129 2005). Eucheuma and Kappaphycus clade A are thought to spread only through vegetative

130 propagation and their distribution has been restricted to Kāne'ohe Bay, whereas Kappaphycus

131 clade B is able to disperse vegetatively and sexually and has been documented outside of

132 Kāne'ohe Bay (Conklin, Kurihara \& Shirwood, 2009). A. spicifera, the most widely distributed

133 non-native macroalgae in Hawai'i (Smith et al., 2002), is thought to have been introduced and

134 spread via ship biofouling or ballast water (Doty 1961, Russel 1983) or possibly through

135 aquarium imports (Russel 1992). A. spicifera is a common fouling species on ship hulls and is

136 able to disperse sexually and via vegetative fragmentation, which may explain its wide

137 distribution (Smith, Hunter \& Smith, 2002). The origin of G. salicornia are speculative, possibly

138 arriving to Hilo Bay in the 1940's associated with ships originating from the Philippines (Smith

139 et al., 2004) and then later intentionally transplanted to various sites around Moloka ‘i and $\mathrm{O}^{`}$ ahu,

140 including Kāne'ohe Bay (Russel, 1992; Smith, Hunter \& Smith, 2002; Smith et al., 2004). G.

141 salicornia is thought to disperse primarily via vegetative fragmentation (Smith et al., 2004).

142

143 All five species are capable of forming dense mats on the reef, overgrowing reef corals, and

144 monopolizing reef habitats (Russel, 1983; Ask and Azanza, 2003; Conklin \& Smith, 2005;

145 Martinez, Smith \& Richmond, 2012). E/K has been shown to be particularly damaging to corals 
146 by shading and smothering live coral and can eventually lead to mortality (Russel, 1983; Woo,

147 2000; Conklin \& Smith, 2005; Chandrasekaran et al., 2008). G. salicornia can also impact reef

148 corals by decreasing irradiance via smothering, altering water chemistry (i.e., hypoxia and

149 hypercapnia) and increasing sedimentation surrounding reef corals (Martinez, Smith \&

150 Richmond, 2012). Although five of these invasive macroalgae species are thought to be

151 damaging to reef biodiversity, $E / K$ were deemed a management priority due to its especially

152 damaging impacts to corals and its limited distribution compared to A. spicifera and G.

153 salicornia (DLNR, 2003).

155 In response to the destructive impact to corals and the concern that $E / K$ would continue to spread

156 and establish on reefs beyond Kāne'ohe Bay, local managers, community members, and

157 researchers worked to develop a control technique for invasive macroalgae with particular focus

158 on $E / K$. Conklin \& Smith (2005) tested various control methods and found that $E / K$ quickly

159 regrew after manual removal, but sea urchin biocontrol showed a sustained reduction of $E / K$ in

160 small-scale field trials. Conklin \& Smith (2005) recommended combining techniques by using

161 manual removal to reduce the bulk of $E / K$ biomass, followed by sea urchins biocontrol treatment

162 to reduce re-growth. Preliminary field trials conducted by Hawai‘i Department of Land and

163 Natural Resources on a patch reef in Kāne'ohe Bay supported this observation (DLNR, 2013).

164 Based on these findings and recommendations, a large-scale invasive macroalgae control project

165 on patch reefs in Kāne'ohe Bay was initiated in 2008 using the combination of manual removal

166 and sea urchin biocontrol.

167 
168 The overarching goal of the project was the rehabilitation and preservation of coral reef habitat

169 and associated biodiversity with specific management objectives to (i) reduce invasive

170 macroalgae on Kāne'ohe Bay patch reefs, and (ii) stop the spread of $E / K$ to unaffected reefs

171 within and outside Kāne'ohe Bay. Although the macroalgae control techniques applied in this

172 study were evaluated previously in small-scale experiments, the combined use of manual

173 removal and sea urchin biocontrol has yet to be tested as a management-relevant, reef-wide scale

174 approach. In this study we evaluate the effectiveness of manual removal combined with urchin

175 biocontrol in sustaining a reduced invasive macroalgae cover [E/K (i.e., Eucheuma,

176 Kappaphycus clade A, Kappaphycus clade B), G. salicornia, A. spicifera] at a reef-wide scale

177 over two years using a Before After Control Impact (BACI) experimental design. We

178 hypothesized that our proposed invasive macroalgae removal and control methods would be

179 effective at maintaining low invasive macroalgae abundance (percent cover) over time at

180 treatment reefs relative to untreated-control reefs. While, a factorial design testing each

181 treatment type separately (i.e., manual removal, biocontrol, and combined treatments) might be

182 preferred, this, was not possible due to logistic and financial challenges associated with

183 implementing and replicating three separate treatment types at the reef-wide scale. However,

184 previous findings of Conklin \& Smith (2005) and data from the State of Hawai'i Division of

185 Aquatic Resources at a scale smaller than the one applied in the current study showed manual

186 removal of invasive algae in the absence of biocontrol cannot successfully reduce invasive

187 macroalgae cover over long term. Simply applying urchin biocontrol without manual removal

188 was also not advised based on concerns of increased fragmentation by urchins detaching

189 holdfasts of large $E / K$ mats. In addition, applying urchins to a large standing crop of macroalgae

190 would increase the amount of urchins, grazing time, and ultimate cost required to successfully 
191 treat a reef. Therefore, our goal was to use a single, most-effective treatment type (i.e., the

192 combination of manual removal and biocontrol) and test whether this treatment was effective at

193 reducing invasive algae cover long term among replicate patch reefs.

195 MATERIALS AND METHODS

\section{Study Site}

197 Invasive macroalgae removal and biocontrol techniques were carried out on four shallow (0.5 -

$1982.0 \mathrm{~m}$ depth) patch reefs located in central Kāne'ohe Bay, on the windward side of O`ahu,

199 Hawai' $\mathrm{i}\left(21^{\circ} 28^{\prime} 0^{\prime \prime} \mathrm{N}, 157^{\circ} 49^{\prime} 0^{\prime \prime} \mathrm{W}\right)$, which is the largest embayment in the Hawaiian Islands and

200 contains over 70 distinct patch reefs surrounded by a barrier reef and fringing reef system (Fig.

201 1). The patch reefs are island-like features separated by $10-15 \mathrm{~m}$ sand bottom. Two patch

202 reefs (Reef 26 and 27) were designated as treatment reefs, where manual removal of $E / K$ and sea

203 urchin biocontrol were applied, and two patch reefs (Reef 16 and 28) were designated as control

204 reefs where no macroalgae manual removal or biocontrol were applied (Fig. 1). Study reefs

205 were selected based on the presence of invasive macroalgae and their close proximity to each

206 other. Designated patch reefs were approximately $11,900 \mathrm{~m}^{2}$ (treatment Reef 26), 12,700 $\mathrm{m}^{2}$

207 (treatment Reef 27), 3,100 $\mathrm{m}^{2}$ (control Reef 16), and 14,500 $\mathrm{m}^{2}$ (control Reef 28). Each patch

208 reef has a distinct reef slope composed primarily of live coral and a shallower reef flat consisting

209 of a mix of live coral, dead coral, rubble, and sand. $E / K$ occurred on reef slopes and reef flats

210 and ranged in size from single low growing thalli to dense mats $1 \mathrm{~m}^{2}$ in area and $\sim 0.3 \mathrm{~m}$ thick

211 (Fig. 2a-b). Gracilaria salicornia and Acanthophora spicifera occurred primarily on the reef

212 flats and also ranged from single thalli to mats $>1 \mathrm{~m}^{2}$ and $\sim 0.1 \mathrm{~m}$ thick (Fig. 2c-d). 


\section{Invasive Macroalgae Control Technique}

215 Invasive macroalgae were controlled in two phases. First, $E / K$ were manually removed from

216 reefs by divers aided by an underwater vacuum system ("The Super Sucker") that transported

217 macroalgae from the reef to a support vessel (Fig. 3a) (Conklin, 2007). To a lesser extent, divers

218 manually removed and bagged macroalgae without aid of the Super Sucker system. At the

219 support vessel, macroalgae was bagged, weighed (wet weight to the nearest $\mathrm{kg}$ ), and then

220 delivered to farmers in the Kāne'ohe Bay watershed for use as an agricultural fertilizer. Manual

221 removal was conducted from November 2011 to March 2012 on treatment Reef 26 over 23

222 working days and treatment Reef 27 was cleared from March 2012 to August 2012 over 25

223 working days (Table 1). Divers removed the bulk of the $E / K$ biomass, leaving macroalgae in

224 hard-to-reach areas (e.g., between coral branches and within crevices), small clumps $\left(<400 \mathrm{~cm}^{3}\right)$

225 and holdfasts to maximize the yield to effort ratio and minimize disturbance to other benthic

226 organisms and habitats. Invasive macroalgae species G. salicornia and A. spicifera were not

227 directly targeted by divers for manual removal.

228

\section{Sea Urchin Biocontrol}

230 Adult Tripneustes gratilla were collected from the wild and spawned at an urchin hatchery.

231 Urchin larvae were settled and reared in tanks on land until they reached approximately $2.5 \mathrm{~cm}$

232 diameter test size ( $\sim 4-6$ months after spawning). A new cohort was produced every $30-60$

233 days throughout the duration of the study. Following $E / K$ manual removal, juvenile urchins were

234 transported to the reef in trays and manually deployed on the treatment reefs where $G$.

235 salicornia, A. spicifera, and E/K occurred (Fig. 3b-d). A systematic approach was used to deploy

236 urchins to achieve a relatively consistent urchin density throughout the entire reef. Urchins were 
237 deployed to the reef as they became available by the hatchery, requiring repeated stocking events

238 to treat each reef. Additional urchins were spot-treated to areas that remained high in invasive

239 macroalgae cover and/or void of urchins as a result of attrition or being inadvertently missed

240 during the initial deployments. Hatchery related biosecurity protocols were followed to prevent

241 the spread of disease and invasive species, and urchins were closely monitored for signs of

242 disease or abnormalities.

243

244 On treatment Reef 26, a total of 46,913 T. gratilla were outplanted to affected areas, the majority 245 of which (76 \% of total) were outplanted from December 2011 to October 2012, with

246 supplemental outplanting from July to December 2013 (19\%) one additional outplanting in July 247 of 2014 ( $13 \%$ and $5 \%$ of total, respectively) (Table 1). On treatment Reef 27 , a total of 52,253

248 urchins were outplanted (Table 1), primarily from August 2012 to May 2013 (97\% of total) with

249 one additional supplemental stocking (1,500 urchins) in December 2013. Stocking density of 250 juvenile urchins was 3.9 urchins $\mathrm{m}^{-2}$ on treatment Reef 26 and 4.2 urchins $\mathrm{m}^{-2}$ on treatment Reef 25127 (Table 1).

252

\section{Invasive Macroalgae Control Costs}

254 Control costs were calculated for field operations (i.e., manual removal and sea urchin 255 outplanting) and sea urchin hatchery operations. Cost estimates included salaries and operating 256 expenses (i.e., equipment, materials, supplies, fuel, and utilities). The total invasive macroalgae 257 control cost of the project was divided by the total reef area treated to estimate cost per square 258 meter. 


\section{Benthic surveys}

261 Baseline benthic surveys were performed at all patch reefs from November 2011 to February

2622012 (hereafter, Winter 2011) prior to macroalgal removal and urchin outplanting representing

263 the "before" period of the analysis. Subsequently, benthic surveys were repeated during the

264 treatment period at four additional times during summer and winter seasons from $2012-2014$,

265 representing the "after" period of the analysis. Sampling periods were defined as: May - June

2662012 (hereafter, Summer 2012), December 2012 - February 2013 (hereafter, Winter 2012), May

267 - June 2013 (hereafter, Summer 2013), and February 2014 (hereafter, Winter 2013). Using these

268 five time points we analyzed changes in percent cover of invasive macroalgae (Eucheuma,

269 Kappaphycus clade B, G. salicornia, A. spicifera), native macroalgae, coral, crustose coralline

270 algae (CCA), and the combined sand/rubble, bare space, turf (thallus length $\leq 10 \mathrm{~mm}$ ) (SBT) at

271 treatment and control reefs.

272

273 Fixed transect locations were randomly selected initially using ArcGIS random point tool (ESRI,

274 2011) within the following strata: windward and leeward prevailing wind orientation (northeast)

275 and habitat type (aggregate reef, mixed/unconsolidated reef, and pavement/consolidated reef

276 situated on reef flat and reef slope areas). In addition to habitat, a windward/leeward

277 stratification was applied to control for the possibility of detached algae collecting

278 disproportionately on the leeward side of reefs as a result of wind driven currents. Reef flat

279 transects ran perpendicular to the prevailing wind direction at a bearing of $\sim 140^{\circ}$. Reef slope

280 transects followed the $\sim 1 \mathrm{~m}$ depth contour clockwise around the reef. The number of transects

281 per reef varied according to reef size at an average sampling effort of one transect per $\sim 800 \mathrm{~m}^{2}$.

282 The total fixed transects for each reef were: 6 (control Reef 16), 18 (control Reef 28), 13 
283 (treatment Reef 26), and 14 (treatment Reef 27). The number of transects were allocated in

284 proportion to the total reef area first, then by primary reef habitats (aggregate and non-

285 aggregate), then by non-aggregate sub-strata (mixed/unconsolidated reef and

286 pavement/consolidated reef). Mean benthic cover was estimated using a point intercept transect

287 method (Hill \& Wilkinson, 2004). Surveyors recorded the benthic cover at $0.2 \mathrm{~m}$ intervals along 288 a $25 \mathrm{~m}$ transect $\left(n=126\right.$ points transect $\left.{ }^{-1}\right) . \quad$. gratilla were surveyed at each transect location, 289 counting all observed individuals within a $25 \times 1 \mathrm{~m}$ belt. A correction factor of $90 \%$

290 detectability (based on F. Mancini and D. Minton field trials) was used to estimate the density of 291 urchins from transect counts.

292

293 Data analysis

294 Response variables (percent cover of invasive macroalgae, native macroalgae, coral, CCA, and

295 SBT) were monitored over time, with baseline surveys at each patch reef (Winter 2011)

296 designated as the "before" period and four subsequent surveys (Summer 2012, Winter 2012,

297 Summer 2013, Winter 2013) designated as "after" periods. Treatment application (i.e., algae

298 removal plus urchin outplanting) was partial in Summer 2012 and complete by Winter 2012

299 (Table 1). Changes in community cover were assessed using a linear mixed effects model fit by

300 restricted maximum likelihood in the lme4 package (Bates et al., 2014) in $R$ version 3.3.0 (R

301 Development Core Team, 2015). Treatment ( $E / K$ manual removal and biocontrol vs. no $E / K$

302 removal or biocontrol) and time (before treatment applied vs. periods after treatment applied)

303 were included as fixed effects. To account for spatial structure of the benthos habitat types

304 within patch reefs (i.e., aggregate reef, mixed/unconsolidated reef, and pavement/consolidated

305 reef) habitat was designated as a random effect nested within individual reefs. Reef transects 
306 were included as a repeated-measure random effect. Considering that surveys conducted over

307 the two-year study period spanning different months and seasons, we first tested 'season' (i.e.,

308 summer $v s$. winter) separately as a fixed effect in a linear model; no effects were observed $(P \geq$

309 0.408) and season was not included in the final analysis. Normality of residuals and

310 homogeneity of variance was verified using graphical inspection of standardized residuals, and

311 transformations were applied where assumptions of ANOVA were not met. An arcsine

312 transformation was used for invasive algae and abiotic cover and a square root transformation

313 was used for CCA and native macroalgae. Analysis of variance tables were generated using

314 type-II sum of squares with Satterthwaite approximations of degrees of freedom using the

315 package lmerTest (Kuznetsova et al., 2016). Where significant interactions were found, posthoc

316 slice tests were performed using lsmeans (Lenth, 2016) to evaluate differences between control

317 and treatment reefs within each sampling time point. All data and code to reproduce figures and

318 analyses can be found on Zenodo (10.5281/zenodo.1285551).

319

320 RESULTS

321 Initial field surveys

322 Mean benthic cover was comparable for all groups (i.e., invasive and native algae, coral, CCA,

323 bare substrate) (posthoc: $p \geq 0.721$ ) at treatment and control reefs at the start of the study (Fig.

324 4a-e). In Winter 2011, benthic cover at the four study reefs was, on average, dominated by hard

325 corals (mean $\pm \mathrm{SE})(39 \pm 13 \%)$, followed by invasive macroalgae $(21 \pm 5 \%), \mathrm{CCA}(5 \pm 2 \%)$,

326 and native macroalgae $(5 \pm 2 \%)$. The native macroalgae community cover was composed

327 primarily of Dictyosphaeria versusii (74 \%) and Dictyosphaeria cavernosa (19\%). Invasive

328 macroalgae on control reefs was predominantly Gracilaria salicornia (11\%), and Eucheuma (7 
$329 \%$ ), whereas invasive macroalgae cover at treatment reefs had similar cover of G. salicornia,

330 Acanthophora spicifera, and Eucheuma (5-7\%) (Fig. 5a-b). Kappaphycus clade B made up

331 the smallest component of the invasive macroalgae community $(0-2.5 \%)$ on all study reefs

332 (Fig. 5a-b). T. gratilla was not detected on control or treatment reefs in the pre-treatment

333 surveys.

335 Macroalgae removal and urchin outplanting surveys

336 Divers removed a total of $11,963 \mathrm{~kg}$ wet weight $\left(0.81 \pm 0.14 \mathrm{~kg} \mathrm{~m}^{-2}\right)$ of $E / K$ from different areas

337 of treatment Reef 26 and 7,095 $\mathrm{kg}$ wet weight $\left(0.622 \pm 0.05 \mathrm{~kg} \mathrm{~m}^{-2}\right)$ from treatment Reef 27

338 (Table 1). The majority of macroalgae was removed using the Super Sucker (80 \%) versus hand

339 removal using bags $(20 \%) . E / K$ was cleared at an average rate of $1.48 \pm 0.14 \mathrm{~m}^{2} \mathrm{~min}^{-1}$. On

340 treatment reefs, the mean $( \pm \mathrm{SE})$ removal effort was greater for Reef $26\left(2.36 \pm 0.27 \mathrm{~m}^{2} \mathrm{~min}^{-1}\right)$

341 compared to treatment Reef $27\left(1.23 \pm 0.10 \mathrm{~m}^{2} \mathrm{~min}^{-1}\right)$ as well as the $E / K$ biomass removed 0.81

$342 \pm 0.14 \mathrm{~kg} \mathrm{~m}^{-2}$ (Reef 26) versus $0.62 \pm 0.05 \mathrm{~kg} \mathrm{~m}^{-2}$ (Reef 27). While stocking density of juvenile

343 urchins was designed to be $\sim 4$ urchins $\mathrm{m}^{-2}$ (Table 1), field surveys following urchin outplanting

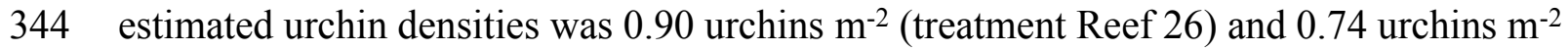

345 (treatment Reef 27). No presence of $T$. gratilla was reported in benthic surveys on control Reefs

$346 \quad 16$ and 28 in post treatment surveys.

347

348 Post-macroalgae removal and urchin outplanting surveys

$349 E / K$ macroalgae manual removal and urchin biocontrol led to an $85 \%$ decline in invasive

350 macroalgae cover over the study period, from $21 \%$ cover in Winter 2011 to $4 \%$ cover in Winter

3512013 (Fig. 4a, 5b, 6). Invasive macroalgae cover was affected by the interaction between 
352 treatment and time (Table 2). On treatment reefs, percent cover of Eucheuma-a target of

353 manual macroalgae removal — had declined by $59 \%$ at the first sampling time (Summer 2012),

354 approximately 6 months after the treatment had been applied (Fig. 5b). However, total invasive

355 macroalgae cover on treatment reefs did not significantly differ from control reefs until one year

356 after the treatment application had begun (posthoc: $p=0.029$ ). By Winter 2012 total invasive

357 macroalgae cover had declined by $29 \%$ relative to Winter 2011 levels. The mean invasive

358 macroalgae cover at control reefs fluctuated between $14-25 \%$ over the entire study period

359 (Winter 2011 to Winter 2013) (Fig. 4a, 6) and comparable across all time points, (posthoc: $p \geq$

360 0.080) except Winter 2013 where invasive algae declined relative to start of the study (posthoc: $p$

$361=0.005)$. G. salicornia and Eucheuma consistently dominated the invasive macroalgae

362 community at control reefs (Fig. 5a), representing mean cover of $7-12 \%$ at each sampling time

363 throughout the study period.

364

365 Mean native macroalgae percent cover ranged from $2-5 \%$ over the study period and decreased

366 over time $(p<0.001)$ but not in response to treatments $(p=0.906)$ (Table 2$)($ Fig. $4 b)$. The

367 interaction of treatment $\times$ time affected coral $(p<0.001)$ and CCA cover $(p=0.037)$, and both

368 coral and CCA increased over the study period $(p<0.001)$. However, mean coral and CCA

369 cover did not differ among control and treatment reefs at each discrete time point (posthoc: $p \geq$

370 0.286). SBT (sand/bare/turf) was not affected by time, treatment, or their interaction $(p \geq 0.255)$

371 (Table 2$)$, but tended to be lower at control reefs $(25-30 \%$ cover $)$ relative to treatment reefs $(35$

$372-40 \%$ cover) (Fig. 4e).

373

374 Invasive Macroalgae Control costs 
375 Field components of macroalgae removal and control operations cost an estimated $\$ 255,000$ and

376 roughly 3,000 human hours of work. Hatchery operations cost $\$ 562,000$, and accounted for

377 approximately 19,000 human hours to run the hatchery facility, which required daily oversight.

378 The total project cost $\$ 817,000$ to treat $24,600 \mathrm{~km}^{2}\left(\$ 33 \mathrm{~m}^{-2}\right)$ of affected reef.

379

380 DISCUSSION

381 Effectiveness of invasive macroalgae control

382 For invasive macroalgae control, there are few demonstrated techniques available for managers

383 when prevention and eradication attempts have failed and valuable resources and biodiversity are

384 at risk (Anderson, 2007). Further, there are few examples of macroalgae control techniques

385 being successfully applied beyond small-scale experiments. The present study demonstrates

386 manual removal of invasive macroalgae, in combination with outplanting hatchery raised

387 juvenile urchins (T. gratilla) for biocontrol, can be an effective approach for reducing the benthic 388 cover of invasive macroalgae at a reef-wide scale. Invasive macroalgae was reduced by $85 \%$,

389 two-years after macroalgae removal and sea urchin biocontrol was applied — a result consistent

390 with a small-scale experiment that employed a similar control technique over a shorter time

391 period (Conklin \& Smith, 2005).

392

393 The treatments applied in this study showed promising results in controlling invasive

394 macroalgae. Manual removal aided by the Super Sucker system was an effective means to

395 remove $E / K$ biomass (51\% decline post manual removal) and was also an efficient means of

396 moving thousands of kilograms of macroalgae from the reef to the support vessel at a mean

397 removal rate of $1.48 \pm 0.14 \mathrm{~m}^{2} \mathrm{~min}^{-1}$. In addition, the vacuum system captured loose 
398 macroalgae fragments created by dislodging the macroalgae, reducing the risk of unintentional

399 dispersal. Following manual removal, invasive macroalgae continued to decline by $61 \%$ from

400 Winter 2012 to Winter 2013 (Fig. 4a). Although individual treatment types were not tested here,

401 we speculate that this decline was a result of $T$. gratilla biocontrol based on the findings of

402 Conklin \& Smith (2005), which documented steady re-growth of $E / K$ without $T$. gratilla

403 biocontrol. It should be noted that manual removal and sea urchin biocontrol manipulations

404 deployed in this study took several months to carry-out (Table 1) and supplemental urchins were

405 added to reefs throughout the study to account for attrition. Therefore, the first "after period"

406 (i.e., Summer 2012) may be viewed as a transitional period in the chronology of our experiment,

407 bridging pre-manipulation and full treatment establishment periods.

408

409 Assessing invasive algae mitigation at reef-wide scales has a strong and direct application to

410 management, however, such studies also present challenges in terms of replication and sample

411 size. Alternatively, studies conducted at smaller spatial scales (i.e., plot-level) offer greater

412 replication, but results may not necessarily be extrapolated to larger scales. In regards to this

413 study, treatments were not fully crossed and replication was low, however, our method are

414 promising, especially in demonstrating the potential for a native, mobile invertebrate as an

415 effective biontrol agent. Despite shortcomings, our results show a clear and lasting results of

416 reduced invasive macroalgae on treatment reefs, indicating our approach was successful and

417 effective in controlling invasive macroalgae over $24,600 \mathrm{~km}^{2}$ of coral reef habitat

419 The sea urchin, T. gratilla, are well suited for mariculture and outplanting for the biocontrol of

420 invasive macroalgae. T. gratilla are able to be propagated in a hatchery using wild stock, 
421 producing large numbers of juvenile urchins $\left(\sim 100,000 \mathrm{yr}^{-1}\right)$ (pers. comm. D. L. Cohen, 2017)

422 without impacting wild $T$. gratilla populations. The small size $(\sim 2.5 \mathrm{~cm}$ test diameter $)$ of

423 outplanted T. gratilla may also be an important factor in treating invasive macroalgae. Chon

424 (2014) found small urchins $(0.5-2.5 \mathrm{~cm}$ test diameter) were more effective at grazing invasive

425 macroalgae than adult $T$. gratilla ( $\sim 4 \mathrm{~cm}$ test diameter) within in situ enclosures. Thus, small

426 test-size urchins appear more capable of grazing holdfasts within the small interstitial spaces of

427 the reef. As juvenile urchins mature, they continue to contribute to invasive macroalgae

428 biocontrol (Chon, 2014; Westbrook et al. 2015), but possibly to a lesser extent. Therefore, the

429 potential for T. gratilla as a biocontrol agent may be size-dependent (Chon, 2014).

430

431 While the primary target species for manual removal was $E / K$, other invasive macroalgae not 432 targeted by manual removal (G. salicornia and A. spicifera) also declined over the study period

433 (Fig. 5b). Potentially, the reductions in G. salicornia and A. spicifera cover at treatment reefs are

434 due to urchin herbivory reducing the cover of these non-targeted (for manual removal) invasive

435 macroalgae. In feeding trials, $T$. gratilla consumed all four species of invasive macroalgae found

436 in this study, but given the choice, urchins preferred A. spicifera, especially among smaller test-

437 size urchins (Westbrook et al., 2015). T. gratilla will also graze G. salicornia, but displays the

438 least preference for this species (Stimson, Cucha \& Philippoff, 2007; Westbrook et al., 2015).

439 Further, Westbrook et al., (2015) found that $T$. gratilla were able to graze invasive macroalgae at

440 a rate of $7.5 \mathrm{~g} \mathrm{~d}^{-1}$ per urchin, which they estimated to be roughly equal to the growth rate of the

441 four species of invasive macroalgae examined.

442 
443 This study demonstrates that $T$. gratilla biocontrol can be successful when applied at the scale of

444 a patch reef $\left(\sim 12,000 \mathrm{~m}^{2}\right)$. However, since urchin movement was naturally confined by $10-15$

$445 \mathrm{~m}$ deep sandy habitats surrounding patch reefs in Kāne'ohe Bay, this raises the question as to

446 whether $T$. gratilla would be as effective in treating larger continuous reefs. Valentine \& Edgar

447 (2010) detected a significant decline of macroalgae on continuous reef habitats when T. gratilla

448 are present in high densities $\left(>4 \mathrm{~m}^{-2}\right)$ at Lord Howe Island. Stimson, Larned \& Conklin (2007)

449 found $T$. gratilla movement to be $<1 \mathrm{~m} \mathrm{~d}^{-1}$ and suggested that this low vagility may explain its

450 generalist diet of a wide range of macroalgae species including non-natives. The low movement

451 rates have allowed Hawai'i managers to utilize $T$. gratilla in spot-treating areas with high

452 invasive macroalgae biomass and apply a manipulated urchin density in problematic locales.

453 Therfore, T. gratilla shows promise as a macroalgae biocontrol agent, but assessing its function

454 in different reef systems should be a priority for future research.

455

456 It is reasonable to acknowledge the potential risk of urchin stocking in Kāne'ohe Bay to facilitate

457 rapid $T$. gratilla population growth. However, we believe this risk is unlikely due to a number of 458 factors, including $T$. gratilla stocking densities were similar to those observed in natural 459 populations on Hawaiian reefs (Walsh et al. 2012). In addition, outplanted urchins remain under 460 pressure from a wide range of natural predators such as fish, decapods, and cephalopods, and 461 urchins were closely monitored by resource managers. Although urchins are reproductively 462 viable, for reasons unknown, conditions in Kāne'ohe Bay have not been favorable for T. gratilla 463 recruitment to patch reefs, and no natural recruitment of hatchery raised T. gratilla in Kāne'ohe 464 Bay has been observed (personal observation). 
466 Invasive macroalgae declined across all four reefs examined in the study, which may have been

467 related to environmental factors such as nutrients, water motion, temperature, and salinity (Glenn

468 \& Doty, 1990) throughout Kāne`ohe Bay. Herbivorous reef fish grazing has also been

469 demonstrated to have a profound impact on macroalgae cover (Williams \& Poluni, 2001;

470 Burkepile \& Hay, 2006; Hughes et al., 2007; Rasher \& Hay, 2013) and may have also

471 contributed to macroalgae decline. For instance, Stamoulis et al., (2017) found G. salicornia

472 was the second most prevalent macroalgae species in gut contents of herbivorous reef fishes in

473 Kāne'ohe Bay. While $E / K$ and $A$. spicifera were also identified in fishes gut contents, these

474 species were far less prevalent (Stamoulis et al., 2017). Although herbivorous fishes appear to

475 be a substantial contributor to controlling invasive macroalgae, protection of herbivorous fishes

476 (in a small marine protected area) alone was not able to reduce invasive macroalgae levels

477 significantly in all reef habitats (Stamoulis et al., 2017). Other Hawaiian reefs that have

478 protection rules in place for herbivores, including T. gratilla, have found significant reductions in

479 macroalgae including A. spicifera (Williams et al., 2016). Based on the findings of this study

480 and others (Conklin \& Smith, 2005; Stimson, Cunha \& Philippoff, 2007; Westbrook et al., 2015;

481 Chon, 2014), T. gratilla appears to be the most effective single biocontrol species when

482 combined with manual removal for treating invasive macroalgae on Hawai'i coral reefs.

483

484 T. gratilla are effective invasive macroalgae grazers (Conklin \& Smith, 2005; Stimson, Cunha \&

485 Philippoff, 2007; Chon, 2014; Westbrook et al., 2015), however, it has been suggested that

486 urchin herbivory may have negative effects. For instance, indiscriminate low-profile grazing on

487 the reef substratum may reduce the survival of juvenile corals (Forsman et al., 2006), newly

488 settled coral recruits, or CCA (Stimson et al., 2007). CCA are an important component of reef 
489 structure and stability (Bak 1976), in addition to providing a substratum for coral recruitment and

490 development (Morse et al., 1996, Negri et al., 2002, Harrington et al., 2004). However, we

491 found no negative effects of treatments (i.e., manual removal + urchin grazing) on coral cover or

492 CCA. Instead, coral cover and CCA showed positive trends through time independent of

493 treatments. Similarly, Stanley (2014) found T. gratilla had no effect on settlement or survival of

494 six Kāne'ohe Bay coral species and Valentine \& Edgar (2010) found T. gratilla outbreaks had no 495 effect on coral cover in Lord Howe Island, Australia. Together, these results suggest T. gratilla 496 stocked at densities for biocontrol actions do not appear detrimental to reef corals or ecologically

497 important CCA. Although no treatment effect of native macroalgae was observed in this study,

498 we speculate that urchin biocontrol may inhibit native macroalgae growth and colonization based 499 on the findings of Valentine and Edgar (2010) following a T. gratilla outbreak and Chon (2014)

500 who found a significant decline in native macroalgae in T. gratilla enclosure experiments at

501 stocking density $>2$ urchins $\mathrm{m}^{-2}$. Although the density of urchins in this study $(0.74-0.9$

502 urchins $\mathrm{m}^{-2}$ ) was lower than Chon's (2014) recommended 2 urchins $\mathrm{m}^{-2}$, it still may be advisable

503 to reduce urchin densities once urchins have grazed invasive macroalgae to $<2 \%$ cover in order

504 to limit potential negative effects on native macroalgae colonization and growth.

506 The observed decrease in invasive macroalgae on control reefs over the course of the study did

507 not result in a significant increase in any single benthic cover type as a result of the treatment

508 (Fig. 4). However, the benthic community composition appears to have changed throughout the

509 course of the study (Fig. 6). This shift from areas dominated by invasive macroalgae to a mix of

510 coral, CCA, native macroalgae, and SBT (sand/bare/turf) may favor the settlement of native flora

511 and fauna and increase the accessibility of suitable settlement substratum. Additionally, the 
512 application of manual removal plus urchin biocontrol resulted in no reductions in ecologically

513 important benthic groups, such as corals and CCA. Approaches to control invasive macroalgae

514 are diverse and not always benign (Anderson, 2007), and applying such treatments on

515 ecologically sensitive habitats, such as coral reefs, demand minimal environmental impacts.

516 Although $E / K$ was carefully hand removed from the reef and fed into the vacuum system, the

517 process does cause low levels of disturbance to the reef including abrasion to coral tissue,

518 dislodgment of benthic organisms and habitat, and the potential for bycatch of small or cryptic

519 organisms associated with macroalgae. It is therefore advised that macroalgae manual removal

520 be performed once or infrequently to reduce the potential for environmental disturbance.

521

522 Manual removal of invasive macroalgae in combination with sea urchin outplanting proved to be 523 a successful approach for invasive macroalgae mitigation in Hawai'i. However, the substantial

524 costs and labor requirements, as well as the necessity of a native herbivore amenable to culturing 525 and outplanting, may limit the broad application of this approach in other reefs or at broader

526 scales than those tested here. Therefore, the effectiveness of this approach on other reef systems

527 required appropriate testing at small experimental scales before reef-wide treatments are applied

528 (Conklin \& Smith, 2005, DLNR, 2013), in addition to long term financial support to advance

529 laboratory tests to the reef-wide scale. Such tests are necessary to evaluate environmental 530 impacts, the need for manual removal, sea urchin biocontrol or both in controlling invasive 531 macroalgae, and weighing logistic and financial constraints.

532

533 Control Costs 
534 The control of invasive macroalgae for this study was a substantial investment by managers at a

535 cost of $\$ 817,000$ to treat $24,600 \mathrm{~km}^{2}\left(\$ 33 \mathrm{~m}^{-2}\right)$ of affected reef. This figure not only

536 demonstrates the need to invest in invasive species prevention through strict vector management

537 and importation rules, but also indicates the importance of Hawai'i's reefs in order to justify such

538 a large expense. Cesar \& Beukering (2003) estimated a 360 million dollar a year net benefit for

539 Hawai'i's economy and a total value of 10 billion dollars. Therefore, investment in restoration

540 and preservation of coral reef ecosystems by controlling invasive macroalgae may be a

541 worthwhile economic investment. It should also be noted that the cost per $\mathrm{m}^{2}$ of treated reef can

542 be reduced by further advances in sea urchin aquaculture.

\section{Conclusion}

545 Our findings show that manual removal and sea urchin biocontrol applied at a reef-wide scale is

546 an effective approach for controlling invasive macroalgae, but should not be viewed as a

547 replacement for managing some of the other drivers of macroalgae phase shifts, including

548 increased nutrients (Lapointe, 1997; Stimson, Larned \& McDermid, 2001), and reduced

549 herbivory (Hay, 1984; Hughes, 1994; Larned, 1998; Bellwood et al., 2004). In addition, the

550 long-term effects ( $>3$ years) are unknown and will require further monitoring in the years to

551 come. The control techniques demonstrated in this study combined with watershed (Richmond

552 et al., 2007) and herbivore (Mumby \& Steneck, 2008) management are necessary to achieve

553 broad goals of reef restoration and habitat improvement. Marine reserves and Herbivore

554 Fisheries Management Areas have shown positive results in Hawai' $i$, by increasing biomass of

555 herbivorous reef fish and reducing cover of invasive macroalgae (Friedlander, Brown \& Monaco,

556 2007; Williams et al., 2016). Unfortunately, native reef fish and urchin assemblages may not be 
557 capable of controlling the combined growth rates of multiple invasive macroalgae species, and

558 therefore, a suite of management strategies may be necessary to control invasive macroalgae at a

559 large-scale.

560

561 Acknowledgements

562 We would like to acknowledge the contribution to this project by the following individuals and 563 organizations: DAR Staff: Jonathan Blodgett, Karen Brittain, Vince Calabrese, David Cohen,

564 Megan Cook, Michael Fujimoto, Justin Goggins, Katharine Hind, Brian Kanenaka, Dan Lager,

565 Derek Levault, Sean Louie, Paul Murakawa, Kimberly Peyton, Andrew Purves, Neil Rodriguez,

566 Brad Stubbs, Kendall Tejchma, Travis Thyberg, Jackie Troller, Ray Uchimura, and Tristen

567 Walker. The Hawai'i Coral Reef Initiative/Social Science Research Institute: Kristine Davidson, 568 Pamela Fujii, Mike Hamnett, and Charissa Minato. The Nature Conservancy: Ryan Carr, Eric

569 Conklin, Justin Dennis, Jan Eber, Kim Hum, Hank Lynch, Dwayne Minton, and Kanekoa Shultz, 570 Eva Zafarano, Kāne`ohe Bay Farmers: Charlie Reppun, John Reppun, and Paul Reppun.

571 Hawai'i Institute of Marine Biology and University of Hawai'i: Megan Donahue, Mary

572 Donovan, Kyle Edwards, Zac Forsman, Erik Franklin, Ku'ulei Rodgers, Kosta Stamoulis, John

573 Stimson, Rob Toonen, and Charley Westbrook. NOAA: Mathew Parry, USFWS: Tony

574 Montgomery, The Pacific Cooperative Studies Unit, and the Research Corporation of the

575 University of Hawai' $i$. We also thank the reviewers for helpful comments on an earlier draft of 576 this manuscript.

577

578

579

580

581

582 
583 LITERATURE CITED

584 FetAnderson LWJ. 2007. Control of Invasive Seaweeds. Bot Mar 50: 418-437

585 Ask EI, Azanza RV. 2002. Advances in cultivation technology of commercial eucheumatoid

586 species: a review with suggestions for future research. Aquaculture 206: 257-277

587

588

589

590

591

592

593

594

595

596

597

598

599

600

601

602

603

604

605

606

607

608

609

610

611

612

613

614

615

616

617

Bak, RPM. 1976. The growth of coral colonies and the importance of crustose coralline algae and burrowing sponges in relation with carbonate accumulation. Neth J Sea Res 10: 285337

Ballesteros E. 2006. Mediterranean coralligenous assemblages: a synthesis of present knowledge. Oceanogr Mar Biol Annu Rev 44:123-195

Douglas Bates, Martin Maechler, Ben Bolker, Steve Walker. 2015. Fitting Linear Mixed-Effects Models Using lme4. J Stat Softw 67: 1-48

Bellwood D, Hughes T, Folke C, Nyström M. 2004. Confronting the coral reef crisis. Nature 429: $827-833$

Boudouresque CF, Lemée R, Mari X, Meinesz A. 1996. The invasive alga Caulerpa taxifolia is not a suitable diet for the sea urchin Paracentrotus lividus. Aquat Bot 53: 245-250

Bruno JF, Selig ER. 2007. Regional decline of coral cover in the Indo-Pacific: timing, extent, and subregional comparisons. PLOS ONE 2: e0000711

Burkepile DE, Hay ME. 2006. Herbivore vs. nutrient control of marine primary producers: context-dependent effects. Ecology 87: 3128-3139

Byers JE. 2002. Impact of nonindigenous species on natives enhanced by anthropogenic alteration of selection regimes. Oikos 97: 449-458

Cebrian J, Shurin JB, Borer ET, Cardinale BJ, Ngai JT, Smith MD, Fagan WF. 2009. Producer nutritional quality controls ecosystem trophic structure. PLoS One 4: e4929

Cesar HSJ, van Beukering PJH. 2004. Economic Valuation of the Coral Reefs of Hawai'i. Pac Sci 58: 231-242

Chandrasekaran S, Nagendran NA, Pandiaraja D, Krishnankutty N, Kamalakannan B. 2008. Bioinvasion of Kappaphycus alvarezii on corals in the Gulf of Mannar, India. Curr Sci 94: $1167-1172$

Cheshire A, Westphalen G, Boxall V, Marsh R, Gilliland J, Collings G, Seddon S, Loo M. 2002. Caulerpa taxifolia in the West Lakes and the Port River, South Australia: distribution, eradication options and consequences. SARDI Aquatic Sciences Publication Number RD02/0161. A Report to the PIRSA Fisheries Marine Habitat Program, 64 Pp

Chon GD. 2014. Optimizing biocontrol: Assessing benthic community changes with different sizes and densities of Tripneustes gratilla on patch reef dominated by invasive Kappaphycus spp. in Kāne`ohe Bay, Hawai'i. MS Thesis. Hawai'i Pacific University 
618 Conklin EJ, Smith JE. 2005. Abundance and spread of the invasive red alga, Kappaphycus spp., 619 in Kane'ohe Bay, Hawai'i and an experimental assessment of management options. Biol $620 \quad$ Invasions 7: 1029-1039

621 Conklin EJ. 2007. The influence of preferential foraging, alien algal species, and predation risk on the interaction between herbivorous fishes and reef macroalgae. Ph.D. thesis. The University of Hawai'i at Manoa, Honolulu, Hawai'i, United States of America. 257 pp

624

625

626

627

628

629

Conklin KY, Kurihara A, Shirwood AR. 2009. A molecular method for identification of the morphologically plastic invasive algal genera Eucheuma and Kappaphycus (Rhodophyta, Gigartinales) in Hawai 'i. J Appl Phycol 21: 691-699

Curiel D, Guidetti P, Bellemo G, Scattolin M, Marzocchi M. 2001. The introduced alga Undaria pinnatifida (Laminariales, Alariaceae) in the Lagoon of Venice. Hydrobiol 477: 209-219

Davidson AD, Campbell ML, Hewitt CL, Schaffelke B. 2015. Assessing the impacts of nonindigenous marine macroalgae: An update of current knowledge. Bot Mar 58: 55-79

De'ath G, Fabricius KE, Sweatman H, Puotinen M. 2012. The 27-year decline of coral cover on the Great Barrier Reef and its causes. P Natl Acad Sci USA 109: 17995-17999

Done TJ. 1992. Phase shifts in coral reef communities and their ecological significance. Hydrobiol 247: 121-132

Doty MS. 1961. Acanthophora, a possible invader of the marine flora of Hawai'i. Pac Sci 15: $547-552$

Doty MS. 1977. Eucheuma - current marine agronomy. In: Klauss R (ed) The Marine Plant Biomass of the Pacific, pp 203-214. Oregon State University Press, Corvallis, OR.

DLNL. 2003. State of Hawai'i Aquatic Invasive Species (AIS) Management Plan. Prepared by the Department of Land and Natural Resources, Division of Aquatic Resources. 1151 Rm 330 Punchbowl St., Honolulu, Hawai'i 96813

DLNR. 2013. Reef 16 pilot project report testing invasive algae control using the Super Sucker and grazing sea urchins. Prepared by the Department of Land and Natural Resources, Division of Aquatic Resources. 1151 Rm 330 Punchbowl St., Honolulu, Hawai'i 96813

Food and Agriculture Organization of the United Nations. 2015. Fisheries and Aquaculture Information and Statistics Services. http:/www.fao.org/figis/ (accessed 13 May 2017)

653

Eakin C, Liu G, Gomez A, De La Cour J, Heron S, Skirving W, Geiger EF, Marsh BL, Tirak $\mathrm{KV}$, Strong AE. 2017. Ding, dong, the witch is dead (?)- Three years of global coral bleaching 2014-2017. Reef Encounter 32: 33-38

www.fao.org/figis/ [accessed 26 July 2014]. 
655

656

657

658

659

660

661

662

663

664

665

666

667

668

669

670

671

672

673

674

675

676

677

678

679

680

681

682

683

684

685

686

687

688

689

690

691

692

693

Forsman ZH, Rinkevich B, Hunter CL. 2006. Investigating fragment size for culturing reefbuilding corals(Porites lobata and P. compressa) in ex situ nurseries. Aquaculture 261: 89-97

Friedlander AM, Brown E, Monaco ME. 2007. Defining reef fish habitat utilization patterns in Hawaii: comparisons between marine protected areas and areas open to fishing. Mar Ecol Prog Ser 351: 221-233

Gardner TA, Cote IM, Gill JA, Grant A, Watkinson AR. 2003. Long-term region-wide declines in Caribbean corals. Science 301: 958-960

Glasby T, Cresse R, Gibson P. 2005. Experimental use of salt to control the invasive marine alga Caulerpa taxifolia in NSW, Australia. Biol Conserv 122: 573-580

Glenn EP, Doty MS. 1990. Growth of the Seaweeds Kappaphycus alvarezii, K. striatum and Eucheuma denticulatum as affected by environment in Hawaii. Aquaculture 84: 245255.

Harrington L, Fabricius K, De'ath G, Negri A. 2004. Recognition and selection of settlement substrata determine post-settlement survival in corals. Ecology 85: 3428-3437

Hay ME. 1984. Predictable spatial escapes from herbivory: how do these affect the evolution of herbivore resistance in tropical marine communities? Oecologia 64: 396-407

Hewitt CL, Campbell ML, McEnnulty F, Moore KM, Murfet NB, Roberston B, Schaffelke B. 2005. Efficacy of physical removal of a marine pest: the introduced kelp Undaria pinnatifida in a Tasmanian Marine Reserve. Biol Invasions 7: 251-263

Hill J, Wilkinson C. 2004. Methods for ecological monitoring of coral reefs. Townsville: Australia Institute of Marine Science $117 \mathrm{pp}$

van Hooidonk, R, Maynard, JA, Planes, S. 2013. Temporary refugia for coral reefs in a warming world. Nat Clim Change 3: 508-511

Hughes TP. 1994. Catastrophes, phase shifts, and large-scale degradation of a Caribbean coral reef. Science 265: 1547-1551

Hughes TP, Rodrigues M, Bellwood D, Ceccarelli D, Hoegh- Guldberg O, McCook L, Moltschaniwskyj N, Pratchett MS, Steneck RS, Willis B. 2007. Phase shifts, herbivory, and the resilience of coral reefs to climate change. Curr Biol 17: 360-365

Hughes TP, Kerry JT, Álvarez-Noriega M, Álvarez-Romero JG, Anderson KD, Baird AH, Babcock RC, Beger M, Bellwood DR, Berkelmans R, Bridge TC, Butler IR, Byrne M, Cantin NE, Comeau S, Connolly SR, Cumming GS, Dalton SJ, Diaz-Pulido G, Eakin CM, Figueira WF, Gilmour JP, Harrison HB, Heron SF, Hoey AS, Hobbs JPA, Hoogenboom MO, Kennedy EV, Kuo CY, Lough JM, Lowe RJ, Liu G, McCulloch MT. Malcom HA, McWilliam MJ, Pandolfi JM, Pears RJ, Pratchett MS, Schoepf V, Simpson T, Skirving WJ, Sommer B, Torda G, Wachenfeld DR, Willis BL, Wilson SK. 2017. Global warming and recurrent mass bleaching of corals. Nature 543: 373-377 
694 Kružić P, Žuljević A, Nikolić V. 2008. The highly invasive alga Caulerpa racemosa var. 695 cylindracea poses a new threat to the banks of the coral Cladocora caespitosa in the $696 \quad$ Adriatic Sea. Coral Reefs 27: 441-441

697 Kuznetsova A, Brockhoff PB, Christensen RHB. 2017. lmerTest Package: Tests in Linear 698 Mixed Effects Models. J Stat Softw, 82: 1-26

699

700

701

702

703

704

705

706

707

708

709

710

711

712

713

714

715

716

717

718

719

720

721

722

723

724

725

726

727

728

Lapointe BE. 1997. Nutrient thresholds for bottom-up control of macroalgae blooms on coral reefs in Jamaica and Southeast Florida. Limnol Oceanogr 42: 1119-1131

Larned ST. 1998. Nitrogen versus phosphorous limited growth and sources of nutrients for coral reef macroalgae. Mar Biol 132: 409-421

Lenth RV. 2016. Least-Squares Means: The R Package lsmeans. J Stat Softw 69: 1-33

Longenecker K, Bolick H, Kawamoto, R. 2011. Macrofaunal invertebrate communities on Hawaii's shallow coral-reef flats: changes associated with the removal of an invasive alien alga. Bishop Museum Technical Report 54, Hawai'i Biological Survey, Bishop Museum. pp. 51.

Loureiro R, Gachon CMM, Rebours C. 2015. Seaweed cultivation: potential and challenge of crop domestication at an unprecedented pace. New Phytol 206: 489-492

Marks LM, Reed DC, Obaza AK. 2017. Assessment of control methods for the invasive seaweed Sargasum horneri in Californa, USA. Management of Biological Invasions 8: 205-213

Martinez JA, Smith CM, Richmond RH. 2012. Invasive algal mats degrade coral reef physical habitat quality. Estua Coast Shelf Sci 99: 42-49

Mate F, Namudu M, Lasi F. 2003. Report on the outcomes of the train-the-trainers workshop on Kappaphycus seaweed farming in Pacific island countries. Tech Rep Mar Stud Programme Univ South Pac 6: 26 pp

Miller AW, Chang AL, Cosentino-Manning N, Ruiz GM. 2004. A new record and eradication of the Northern Atlantic alga Ascophyllum nodosum (Phaeophyceae) from San FranciscoBay, California, USA. J Phycol 40: 1028-1031

Moburg F, Folke C. 1999. Ecological goods and services f coral reef ecosystems. Ecol Econ 29: 215-233

Morse ANC, Iwao K, Baba M, Shimoike K, Hayashibara T, Omori M. 1996. An ancient chemosensory mechanism brings new life to coral reefs. Biol Bull 191: 149-154

Mumby PJ, Steneck RS. 2008. Coral reef management and conservation in light of rapidly evolving ecological paradigms. Trends Ecol Evol 23: 555-563

Murphy JWA, Richmond RH. 2016. Changes to coral and health and metabolic activity under oxygen deprivation. PeerJ 4: e1956 
729

730

731

732

733

734

735

736

737

738

739

740

741

742

743

744

745

746

747

748

749

750

751

752

753

754

755

756

757

758

759

760

761

762

763

764

765

Naylor RL, Williams SL, Strong DR. 2001. Aquaculture-a gateway for exotic species. Science 294: 1655-1656.

Negri AP, Webster NS, Hill RT, Heyward AJ. 2001. Metamorphosis of broadcast spawning corals in response to bacteria isolated from crustose algae. Mar Ecol Prog Ser 223: 121131

Nyberg CD, Wallentinus I. 2005. Can species traits be used to predict marine macroalgal introductions? Biol Invasions 7: 265-279

Pan RT. 2012. The growth and survival of the sea urchin Tripneustes gratilla, a possible biocontrol agent for invasive macroalgae. MS Thesis. University of Hawai'i, HI. 82 pp

Pandolfi JM, Bradbury RH, Sala E, Hughes TP, Bjorndal KA, Cooke RG, McArdle D, McClenachan L, Newman MJ, Paredes G, Warner RR, Jackson JB. 2003. Global trajectories of the long-term decline of coral reef ecosystems. Science 301: 955-958

Pickering T, Forbes A. 2002. The progress of aquaculture development in Fiji. Technical Report, Marine Studies Programme, University of South Pacific 2002/1: 40 pp

Radulovich R, Umanzor S, Cabrera R, Mata R. 2015. Tropical seaweeds for human food, their cultivation and its effect on biodiversity enrichment. Aquaculture 436: 40-46

Rasher DB, Hay ME. 2010. Chemically rich seaweeds poison corals when not controlled by herbivores. P Natl Acad Sci USA 107: 9683-9688

Rasher DB, Hoey AS, Hay ME. 2013. Consumer diversity interacts with prey defenses to drive ecosystem function. Ecology 94: 1347-1358

Richmond RH, Rongo T, Golbuu Y, Victor S, Idechong N, Davis G, Kostka W, Neth L, Hamnett M, Wolanski E. 2007. Watershed and coral reefs: conservation science, policy, and implementation. Bioscience 57: 598-607

Rodgers SK, Cox EF. 1999. Rate of Spread of Introduced Rhodophytes Kappaphycus alvarezii, Kappaphycus striatum, and Gracilaria salicornia and their current distribution in Kane'ohe Bay, O'ahu, Hawai'i. Pac Sci 53: 232-241

Ruiz GM, Fofonoff P, Hines AH, Grosholz ED. 1999. Non-indigenous species as stressors in estuarine and marine communities: Assessing invasion impacts and interactions. Limnol Ocenogr 44: 950-72.

Ruiz RM, Fofonoff PW, Carlton JT, Wonham MJ, Hines AH. 2000. Invasion of coastal marine communities in North America: apparent patterns, processes, and biases. Annu Rev Ecol Syst 31: 481-531

Russell DJ. 1983. Ecology of the imported red seaweed Eucheuma striatum Schmitz on Coconut Island, O‘ahu, Hawai'i. Pac Sci 37: 87-107

Russell DJ. 1992. The ecological invasion of Hawaiian reefs by two marine red algae, Acanthophora spicifera (Vahl) Boerg. and Hypnea musciformis (Wulfen) J. Ag., and 
766

767

768

769

770

771

772

773

774

775

776

777

778

779

780

781

782

783

784

785

786

787

788

789

790

791

792

793

794

795

796

797

798

799

800

their association with two native species, Laurencia nidifica J. Ag. and Hypnea cervicornis J Ag. ICES Mar Sci194: 110-125

Schaffelke B, Smith JE, Hewitt CL. 2006. Introduced macroalgae - A growing concern. In: Anderson R, Brodie J, Onsøyen E, Critchley AT. (eds) Eighteenth International Seaweed Symposium. Developments in Applied Phycology, vol 1. Springer, Dordrecht

Schaffelke B, Hewitt CL. 2007. Impacts of introduced seaweeds. Bot Mar 50: 397-417

Schaffelke B, Evers D, Walhorn A. 1995. Selective grazing of the isopod Idotea baltica between Fucus evanescens and F. vesiculosus from Kiel Fjord (western Baltic). Mar Biol 124: $215-218$

Scheibling RE, Hatcher BG. 2007. The ecology of Strongylocentrotus droebachiensis. Pages 353-382 in J. M. Lawrence, editor. Edible sea urchins: biology and ecology.

Developments in Aquaculture and Fisheries Science 37. Elsevier Science, Amsterdam, The Netherlands

Sellers A, Saltonstall K, Davidson T. 2015. The introduced alga Kappaphycus alvarezii (Doty ex P.C. Silva, 1996) in abandoned cultivation sites in Bocas del Toro, Panama. BioInvasions records 4: 1-7

Smith JE, Smith CM, Hunter CL. 2001. An experimental analysis of the effects of herbivory and nutrient enrichment on benthic community dynamics on a Hawai'ian reef. Coral Reefs 19: 332-342

Smith JE, Hunter CL, Smith CM. 2002. Distribution and reproductive characteristics of nonindigenous and invasive marine algae in the Hawaiian Islands. Pac Sci 56: 299-315

Smith JE, Hunter CL, Conklin EJ, Most R, Sauvage T, Squair C, Smith CM. 2004. Ecology of the Invasive Red Alga Gracilaria salicornia (Rhodophyta) on O`ahu, Hawai'i. Pac Sci 58: $325-343$

Smith SV, Kimmerer WJ, Laws EA, Brock RE, Walsh TW. 1981. Kāne‘ohe Bay sewage diversion experiment: perspectives on ecosystem responses to nutritional perturbation. Pac Sci 35: 279-395

Stamoulis KA, Friedlander AM, Meyer CG, Fernandez-Silva I, Toonen RJ. 2017. Coral reef grazer-benthos dynamics complicated by invasive algae in a small marine reserve. Sci Rep 7: 43819

Stanley LA. 2014. Patterns of coral recruitment in the presence of invasive algae and sea urchin biocontrol. MS Thesis. Hawai'i Pacific University, HI. 66 pp

Stimson JS, Larned ST, McDermid K. 1996. Seasonal growth of the coral reef macroalga Dictyosphaeria cavernosa (Forskal) Borgesen and the effects of nutrient availability, temperature and herbivory on growth rate. J Exp Mar Bio Ecol 196: 53-67 
801 Stimson JS, Larned ST, Conklin EJ. 2001. Effects of herbivory, nutrient levels, and introduced

802

803

804

805

806

807

808

809

810

811

812

813

814

815

816

817

818

819

820

821

822

823

824

825

826

827

828

829

830

831

832

833

834

835

836

837

838 algae on the distribution and abundance of the invasive macroalga Dictyosphaeria cavernosaa in Kane'ohe Bay, Hawai'i. Coral Reefs 19: 343-357

Stimson JS, Cunha T, Philippoff J. 2007. Food preferences and related behavior of the browsing sea urchin Tripneustes gratilla (Linnaeus) and its potential for use as biological control agent. J Mar Biol 151: 1761-1772

Thacker RW, Ginsberg DW, Paul VJ. 2001. Effects of herbivore exclusion and nutrient enrichment on coral reef macroalgae and cyanobacteria. Coral Reefs 19: 318-329

Thibaut T, Meinesz V. 2000. Are the Mediterranean ascoglossan molluscs Oxynoe ulivacen and Lobiger serradifalci suitable agents for a biological control against the invading tropical alga Caulerpa taxifolia CR Acad Sci III 323: 477-488

Valentine JP, Edgar GJ. 2010. Impacts of a population outbreak of the urchin Tripneustes gratilla amongst Lord Howe Island coral communities. Coral Reefs 29: 399-410

Vermeij MJ, Smith T, Dailer M, Smith C. 2009. Release from native herbivores facilitates the persistence of invasive marine algae: a biogeographical comparison of the relative contribution of nutrients and herbivory to invasion success. Biol Invasions 11: 1463-1474

Walsh W, Cotton S, Barnett C, Couch C, Preskitt L, Tissot B, Osada-D’Avella K. 2012. Longterm monitoring of coral reefs of the main Hawaiian Islands. Final report prepared for the NOAA Coral Reef Conservation Program, Hawaii Division of Aquatic Resources. 97 p.

Westbrook CE, Ringang RR, Cantero SMA, HDAR and TNC urchin team, Toonen RJ. 2015. Survivorship and feeding preferences among size classes of outplanted sea urchins, Tripneustes gratilla, and possible use as biocontrol for invasive alien algae. PeerJ 3: e1235

Williams ID, Polunin NVC. 2001. Large-scale associations between macroalgal cover and grazer biomass on mid-depth reefs in the Caribbean. Coral Reefs 19: 358-366

Williams ID, White DJ, Sparks RT, Lino KC, Zamzow JP, Kelly ELA, Ramey HL. 2016. Response of herbivore fishes and benthos to 6 years protection at Kahekili Herbivore Fisheries Management Area, Maui. PLoS ONE 11:159100

Williams SL, Smith JE. 2007. A global review of the distribution, taxonomy, and impacts of introduced seaweeds. Annu Rev Ecol Evol Sys 38: 327-359

Williams SL, Smith SL. 2004. Eradication of the invasive seaweed Caulerpa taxifolia by chlorine bleach. Mar Ecol Prog Ser 272: 69-76

Woo M. 2000. Ecological impacts and interactions of the introduced red alga Kappaphycus striatum in Kane'ohe Bay, O'ahu. Master's thesis, Department of Botany, University of Hawai'i, Honolulu, HI

Wotton D, Hewitt C. 2004. Marine biosecurity post-border management: developing incursion response systems for New Zealand. NZ J Mar Freshw Res 38: 553-559 
839

840

841

842

843

844

845

846

847

848

849

850

851

852

853

854

855

856

857

858

859

860

861

862

863

864

865

866

867

868

869

870

871

872

873

874

875

876

877

878

879

880

881

Zemke-White WL, Smith JE. 2006. Environmental impacts of seaweed farming in the tropics. In: Critchley AT, Ohno M, Largo D (eds) World Seaweed Resource., (CD-ROM series) ETI BioInformatics, University, Amsterdam, 1-42 pp

Zhang QS, Tang XX, Cong YZ, Qu SC, Luo SJ, Yang GP. 2007. Breeding of an elite Laminaria variety 90-1 through inter-specific gametophyte crossing. J App Phycol 19: 303-311.

Zuccarello GC, Smith JE, West JA. 2006. Systematic and genetic variation in commercial Kappaphycus and Eucheuma (Solieriaceae, Rhodophyta). J Phycol 18: 643-651

Table 1. Invasive macroalgae manual removal and Tripneustes gratilla outplanting dates, area, and stocking density.

Table 2. Analysis of variance table for treatment and time effects on coral reef community cover.

Fig. 1. Study site location in Kāne'ohe Bay on the windward side of the island of O'ahu, Hawai'i, proximate to Moku o Lo'e (Hawai'i Institute of Marine Biology).

Fig. 2. Invasive macroalgae species found on study reefs in Kāne'ohe Bay: (A) Eucheuma clade E, (B) Kappaphycus clade A, (C) Gracilaria salicornia, (D) Acanthophora spicifera (photo credit: Brian Neilson).

Fig. 3. Invasive macroalgae control techniques applied in the field (A) using the Super Sucker to manually remove Eucheuma clade E, (B) outplanting juvenile Tripneustes gratilla, (C) outplanted adult $T$. gratilla surrounded by Gracilaria salicornia and Acanthophora spicifera, (D) adult $T$. gratilla surrounded by Eucheuma clade E, (E) before and immediately (F) after manual removal of Eucheuma clade E revealing crustose coralline algae (CCA) and (G) before and (H) after removal of Eucheuma clade E revealing live and dead coral (photo credit: (A-B) DLNR/DAR, (C-H) Brian Neilson).

Fig. 4. Mean percent cover for (A) combined invasive macroalgae (Eucheuma clade E /Kappaphycus Clade B/Acanthophora spicifera/Gracilaria salicornia), (B) native macroalgae, (C) crustose coralline algae (CCA), (D) corals, and (E) SBT (sand/bare/turf). Value are mean \pm SE; $n=24$ (control) and $n=26-27$ (treatment) for each sampling time. The first time point in each figure (Winter 2011) represents the "before" time period of the study and all subsequent time points represent the "after" period.

Fig. 5. Percent cover for invasive macroalgae species through time at (A) control reefs and (B) treatment reefs. Value are mean $\pm \mathrm{SE} ; n=24$ (control reefs) and $n=26-27$ (treatment reefs) for each sampling time.

Fig. 6. Mean percent cover for benthic community members at control and treatment reefs before applying treatments (Winter 2011) and two years after treatment application (Winter 2013). Value are mean $\pm \mathrm{SE} ; n=24$ (control) and $n=26-27$ (treatment) for each sampling time. 


\section{Table $\mathbf{1}$ (on next page)}

Invasive macroalgae manual removal and Tripneustes gratilla outplanting dates, area, and stocking density. 
Table 1. Invasive macroalgae manual removal and Tripneustes gratilla outplanting dates, area, and stocking density.

\begin{tabular}{|c|c|c|c|c|c|c|c|}
\hline $\begin{array}{l}\text { Treatment } \\
\text { Reef }\end{array}$ & $\begin{array}{c}\text { Manual } \\
\text { Removal } \\
\text { Dates } \\
\end{array}$ & $\begin{array}{c}\text { Manual } \\
\text { Removal } \\
\text { Days }\end{array}$ & $\begin{array}{c}E / K \\
\text { Removed } \\
(\mathrm{kg})\end{array}$ & $\begin{array}{c}\text { Urchin } \\
\text { Outplanting } \\
\text { Dates } \\
\end{array}$ & $\begin{array}{c}\text { Urchin } \\
\text { Outplanting } \\
\text { Area }\left(\mathrm{m}^{2}\right) \\
\end{array}$ & $\begin{array}{l}\text { Urchins } \\
\text { Stocked }\end{array}$ & $\begin{array}{c}\text { Urchin } \\
\text { Stocking Density } \\
\left(\text { urchins } m^{-2}\right) \\
\end{array}$ \\
\hline Reef 26 & $\begin{array}{l}\text { Nov } 2011- \\
\text { Mar } 2012\end{array}$ & 23 & 11,963 & $\begin{array}{l}\text { Dec } 2011- \\
\text { Dec } 2013\end{array}$ & 11,900 & 46,913 & 3.94 \\
\hline Reef 27 & $\begin{array}{l}\text { Mar 2012- } \\
\text { Aug-2012 }\end{array}$ & 25 & 7,095 & $\begin{array}{l}\text { Aug } 2012- \\
\text { Dec } 2013 \\
\end{array}$ & 12,700 & 52,835 & 4.16 \\
\hline Total & $\begin{array}{l}\text { Nov } 2011- \\
\text { Aug-2012 }\end{array}$ & 48 & 19,058 & $\begin{array}{l}\text { Dec } 2011- \\
\text { Dec } 2013\end{array}$ & 24,600 & 99,748 & 4.05 \\
\hline
\end{tabular}

2

3 


\section{Table 2 (on next page)}

Analysis of variance table for treatment and time effects on coral reef community cover.

Linear mixed effect models fit by restricted maximum likelihood; analysis of variance table of Type II sum of squares and Satterthwaite approximation for degrees of freedom. Invasive macroalgae = Eucheuma denticulatum, Kappaphycus alvarezii, Acanthophora spicifera, Gracilaria salicornia; $C C A=$ crustose coralline algae; $S S=$ sum of squares; $d f=$ degrees of freedom in numerator and denominator; bold $p$ values represent significant effects $(p<$ 0.05). 
Table 2. Analysis of variance table for treatment and time effects on coral reef community cover.

\begin{tabular}{llrrrr}
\hline \hline Dependent variable & Effect & \multicolumn{1}{c}{ SS } & \multicolumn{1}{c}{$d f$} & \multicolumn{1}{c}{$F$} & \multicolumn{1}{c}{$p$} \\
\hline Invasive macroalgae & Treatment & 0.031 & 1,9 & 3.377 & 0.098 \\
& Time & 1.478 & 4,195 & 40.389 & $<\mathbf{0 . 0 0 1}$ \\
& Treatment $\times$ Time & 0.629 & 4,195 & 17.202 & $<\mathbf{0 . 0 0 1}$ \\
& & & & & \\
Native macroalgae & Treatment & 0.0005 & 1,9 & 0.015 & 0.906 \\
& Time & 0.120 & 4,195 & 8.841 & $<\mathbf{0 . 0 0 1}$ \\
& Treatment $\times$ Time & 0.026 & 4,195 & 1.928 & 0.107 \\
& & & & & \\
CCA & Treatment & 0.0005 & 1,9 & 0.045 & 0.837 \\
& Time & 0.366 & 4,195 & 9.194 & $<\mathbf{0 . 0 0 1}$ \\
& Treatment $\times$ Time & 0.104 & 4,195 & 2.606 & $\mathbf{0 . 0 3 7}$ \\
& & & & & \\
Coral & Treatment & 0.0001 & 1,9 & 0.056 & 0.818 \\
& Time & 0.181 & 4,195 & 34.783 & $<\mathbf{0 . 0 0 1}$ \\
& Treatment $\times$ Time & 0.020 & 4,195 & 3.867 & $\mathbf{0 . 0 0 5}$ \\
Sand/bare/turf & Treatment & & & & \\
& Time & 0.007 & 1,9 & 0.520 & 0.489 \\
& Treatment $\times$ Time & 0.072 & 4,195 & 1.344 & 0.255 \\
& & 0.048 & 4,195 & 0.893 & 0.469 \\
\hline
\end{tabular}

Linear mixed effect models fit by restricted maximum likelihood; analysis of variance table of Type II sum of squares and Satterthwaite approximation for degrees of freedom. Invasive macroalgae = Eucheuma denticulatum, Kappaphycus alvarezii, Acanthophora spicifera, Gracilaria salicornia; $\mathrm{CCA}=$ crustose coralline algae; $S S=$ sum of squares; $d f=$ degrees of freedom in numerator and denominator; bold $p$ values represent significant effects $(p<$ $0.05)$ 
Figure 1

Study site location in Kāne'ohe Bay on the windward side of the island of O'ahu, Hawai' $\mathrm{i}$, proximate to Moku o Lo'e (Hawai'i Institute of Marine Biology). Baseline image provided by $\odot$ DigitalGlobe, Inc., All Rights Reserved. 


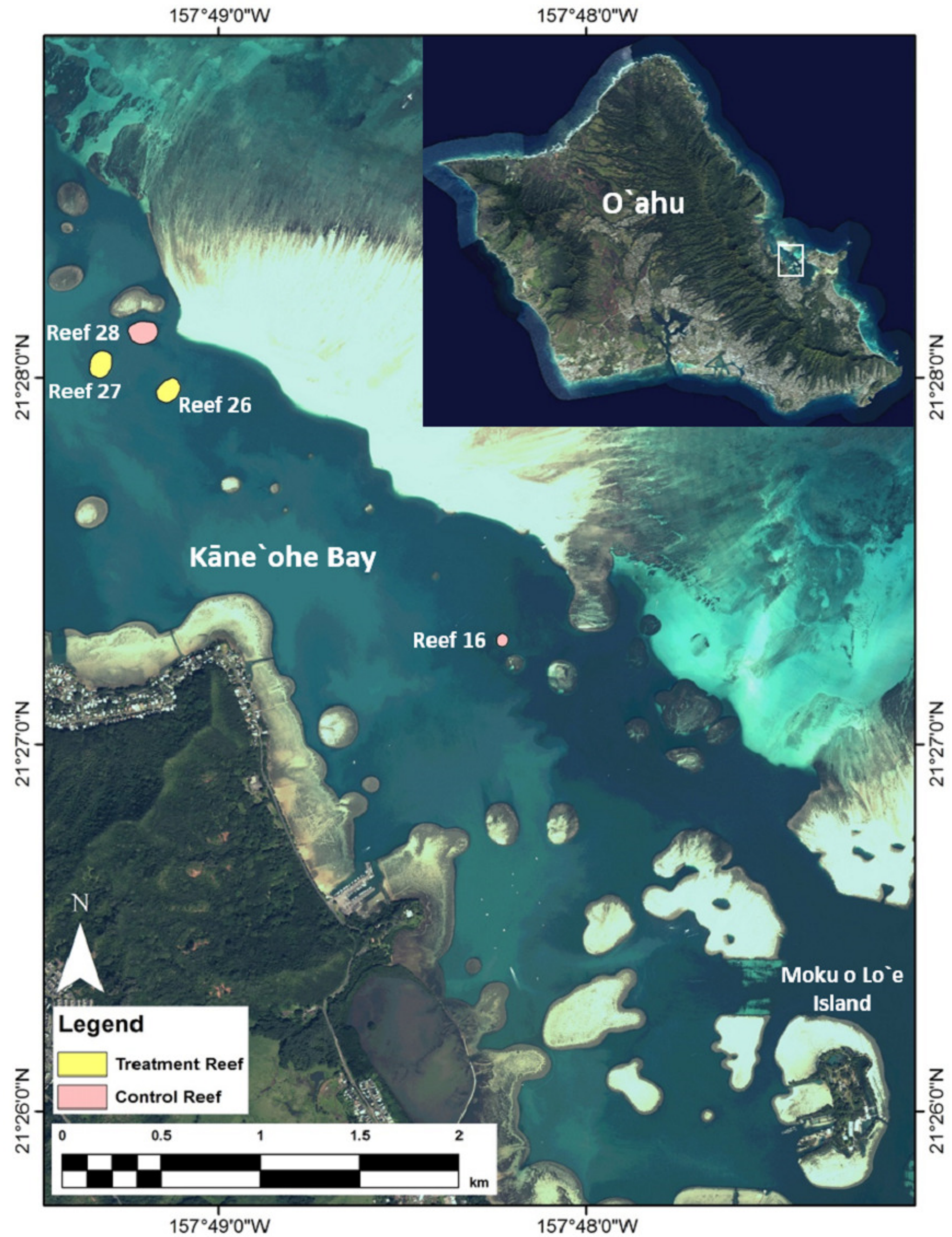


Figure 2

Invasive macroalgae species found on study reefs in Kāne'ohe Bay

(A) Eucheuma clade E, (B) Kappaphycus clade B, (C) Gracilaria salicornia, (D) Acanthophora spicifera (photo credit: Brian Neilson.
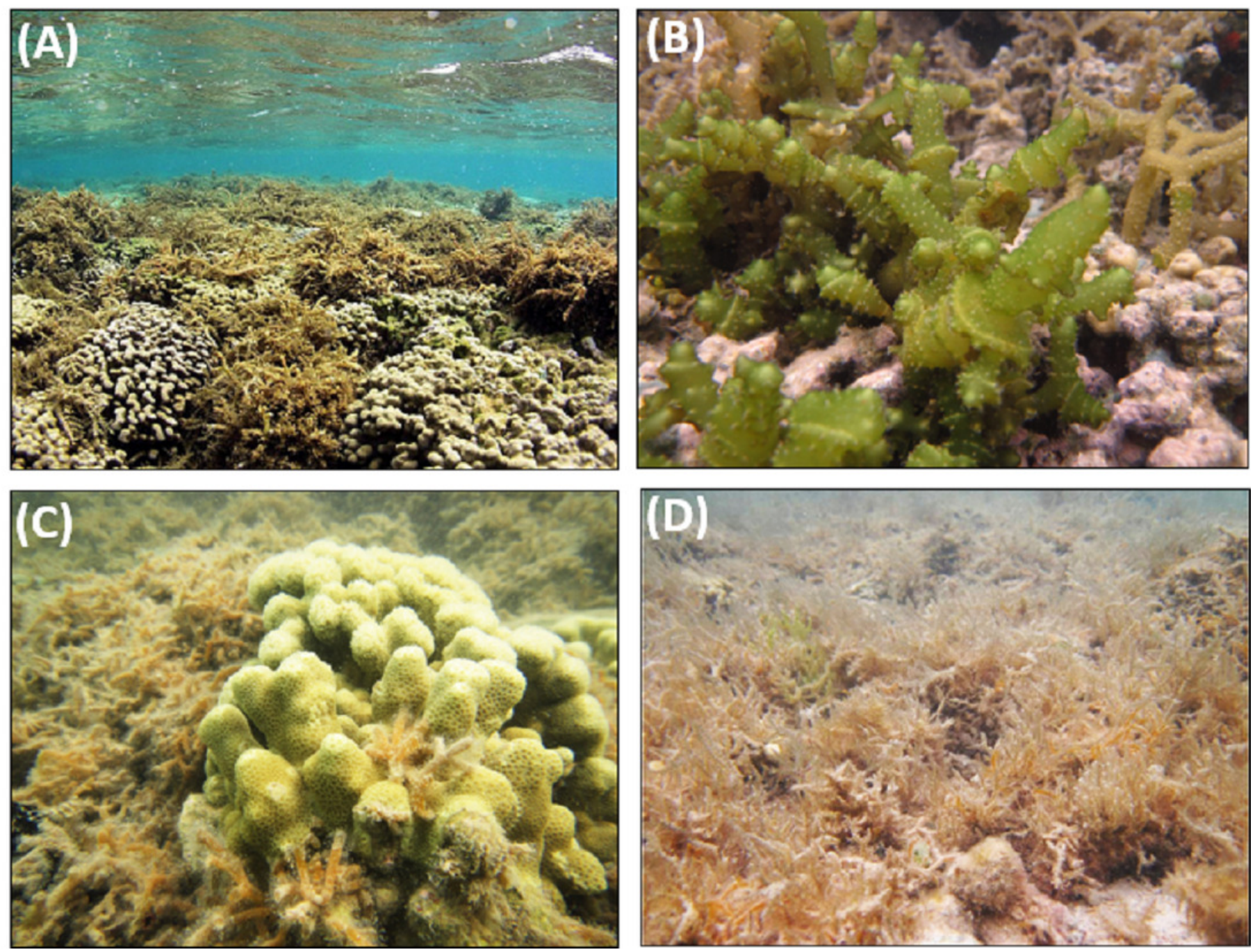


\section{Figure 3}

Invasive macroalgae control techniques applied in the field.

(A) using the Super Sucker to manually remove Eucheuma clade E, (B) outplanting juvenile Tripneustes gratilla, (C) outplanted adult $T$. gratilla surrounded by Gracilaria salicornia and Acanthophora spicifera, (D) adult T. gratilla surrounded by Eucheuma clade E, (E) before and immediately (F) after manual removal of Eucheuma clade E revealing crustose coralline algae $(\mathrm{CCA})$ and $(\mathrm{G})$ before and $(\mathrm{H})$ after removal of Eucheuma clade $\mathrm{E}$ revealing live and dead coral (photo credit: (A-B) DLNR/DAR, (C-H) Brian Neilson). 

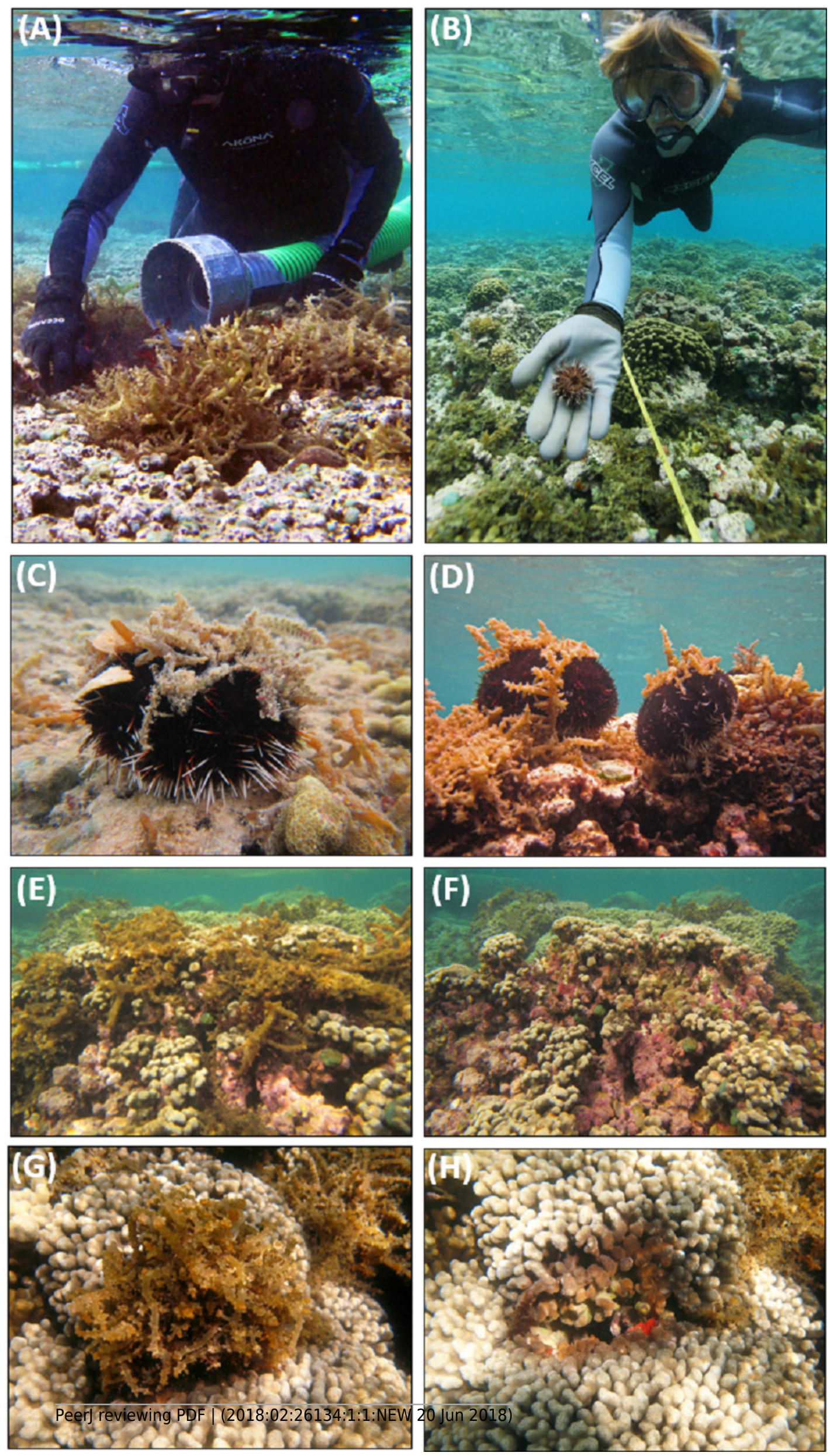
Figure 4 (on next page)

Mean percent cover of benthic cover types

(A) combined invasive macroalgae (Eucheuma clade E/Kappaphycus Clade B/Acanthophora spicifera/Gracilaria salicornia), (B) native macroalgae, (C) crustose coralline algae (CCA), (D) corals, and (E) SBT (sand/bare/turf). Value are mean \pm SE; $n=24$ (control) and $n=26-27$ (treatment) for each sampling time. The first time point in each figure (Winter 2011) represents the "before" time period of the study and all subsequent time points represent the "after" period. Symbols $(*)$ represent a significant difference $(p \leq 0.05)$ between the control and treatment. 
Figure 5 (on next page)

Percent cover for invasive macroalgae species through time

(A) control reefs and (B) treatment reefs. Value are mean $\pm \mathrm{SE} ; n=24$ (control reefs) and $n$ $=26-27$ (treatment reefs) for each sampling time. 


\section{Control Reeefts}

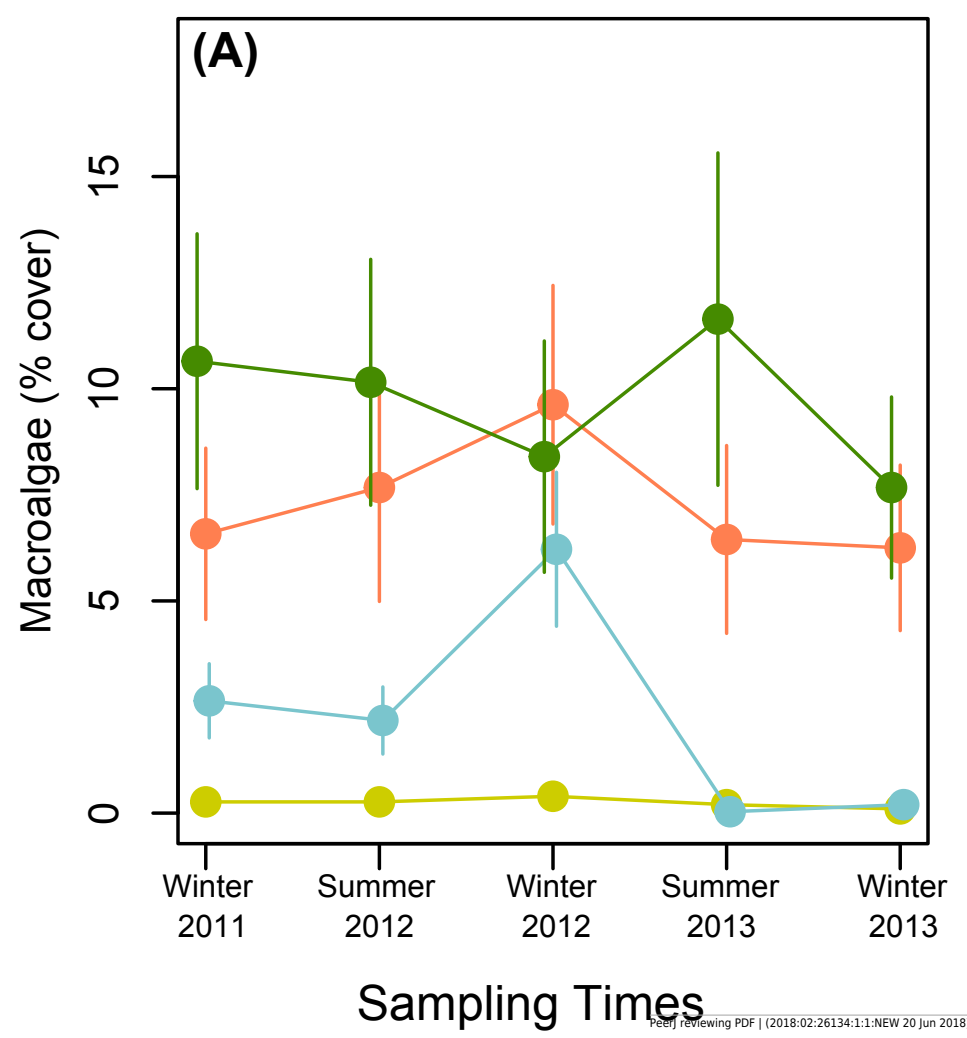

Manuscript to be reviewed Treatment Reefs

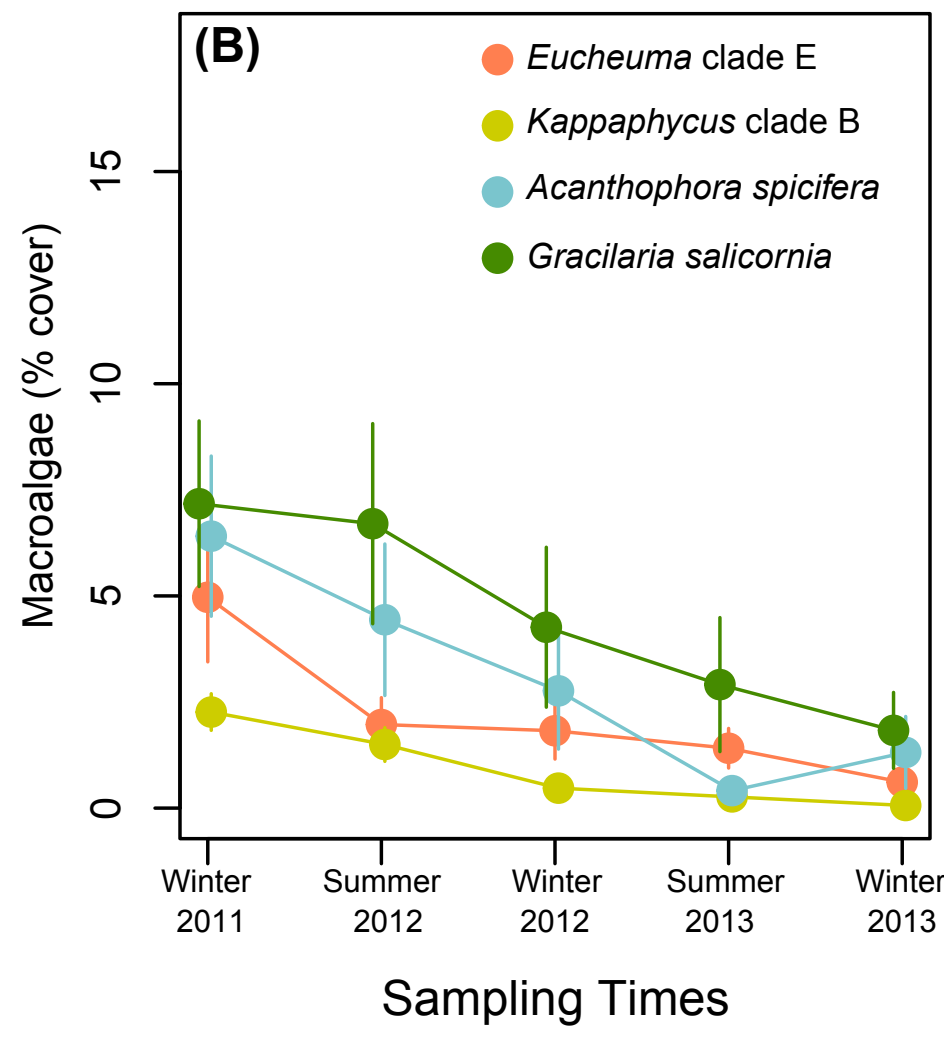


Figure 6 (on next page)

Mean percent cover for benthic community members at control and treatment reefs before applying treatments (Winter 2011) and two years after treatment application (Winter 2013).

Value are mean $\pm \mathrm{SE} ; n=24$ (control) and $n=26-27$ (treatment) for each sampling time. 
Before: Winter 2011

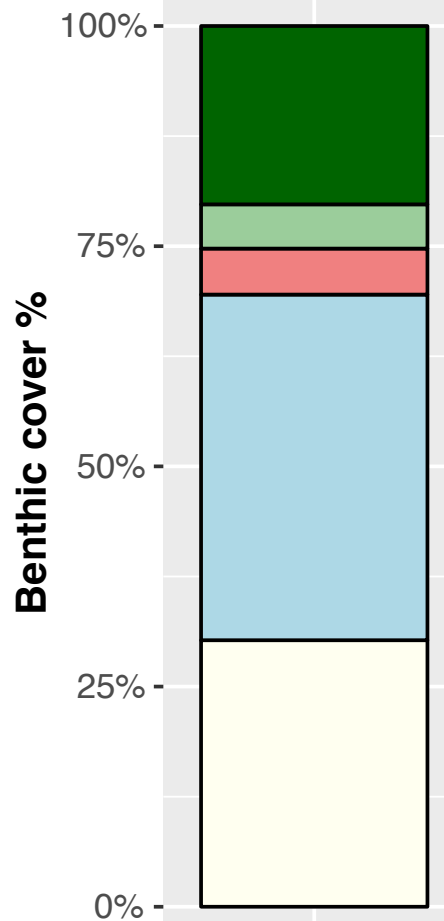

Control Algae removal + urchins
After: Winter 2013
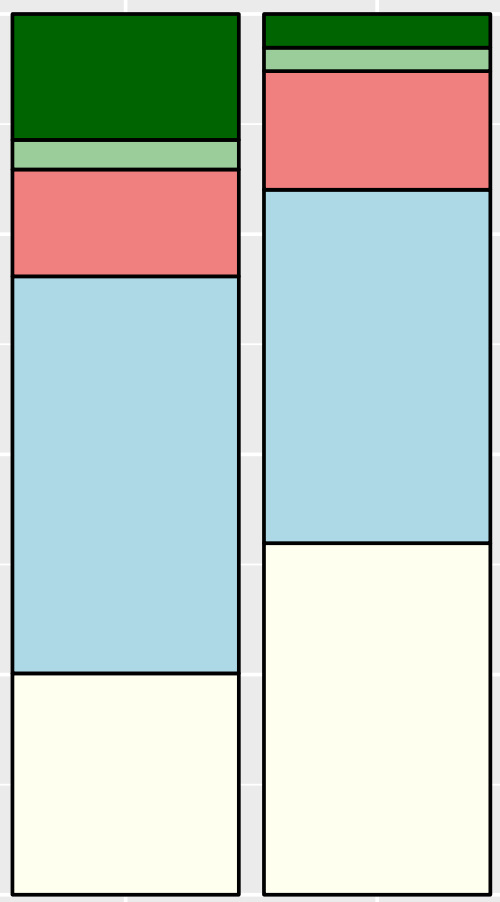

Control

Community members Invasive macroalgae

Native macroalgae

$\longrightarrow \mathrm{CCA}$

Coral SBT

Algae removal + urchins 